\title{
THE PLIGHT OF SMALL ISSUERS UNDER THE SECURITIES ACT OF I933: PRACTICAL FORECLOSURE FROM THE CAPITAL MARKET
}

\author{
RUTHEFORD B. CAMPBELl, JR.*
}

\section{INTRODUCTION}

The thesis of this Article is simple: the Securities Act of $1933^{1}$ does not work very well for small issuers, a premise which the Securities and Exchange Commission appeared to tacitly recognize in a series of announcements released early this year. ${ }^{2}$ Because of a combination of exorbitant costs, unmanageable levels of ambiguity, unworkable resale provisions and contamination caused by prior illegal sales of stock, a small issuer often is unable to comply with the 1933 Act. As a result it may be difficult or even impossible for a small issuer to raise capital by selling stock.

There are obvious pernicious effects caused by this inability to exploit one form of financing. One such effect is that both the issuer and society may be denied the benefits of competition if the issuer is unable to secure the funds necessary for expansion. Although it cannot be seriously contended that alterations in the 1933 Act suddenly can turn around a faltering economy or interject meaningful competition in traditionally oligopolistic industries, the 1933 Act does unreasonably impede the capital formation that small businesses require in order to have any chance of competing with larger concerns.

* Associate Professor of Law, University of Kentucky College of Law; Visiting Associate Professor of Law, University of Maine School of Law, 1978; B.A. 1966, Centre College; J.D. 1969, University of Kentucky; LL.M. 1971, Harvard University.

THE FOLLOWING CITATIONS WILL BE USED IN THIS ARTICLE:

L. Loss, SECurities Regulation (2d ed. 1961) [hereinafter cited as Loss];

Hicks, Intrastate Offering Under Rule 147, 72 MiCH. L. REv. 463 (1974) [hereinafter cited as Hicks];

Schwartz, Rule 146: The Private Offering Exemption-Historical Perspective and Analysis, 35 OHı ST. L.J. 738 (1974) [hereinafter cited as Schwartz].

1. 15 U.S.C. $\$ \S 77 a-77 a a(1970)$.

2. In March of 1978 there was a flurry of activity from the Commission on the problems of small issuers. Perhaps the most significant of the Commission's actions was the announcement that public hearings would be held in order to solicit comments concerning the special problems of small issuers. Securities Act Release No. 5914 (Mar. 6, 1978), [Current] FED. SEC. L. REP. (CCH) I 81,530. Although it is difficult to define a "small issuer" or "small company," those terms when used in this Article will refer to a company that possesses two characteristics: first, a relatively small pool of income-earning assets, and second, issued stock of the company that is not widely traded, thereby resulting in no active or organized market for the stock. If both of these characteristics are present, all the problems and resulting unfairness described in this Article will be present with respect to the issuer. To the extent that only one characteristic is present, some of the problems discussed in this Article will be eliminated. 
It should be made clear at the outset that the thesis of this Article is not that the 1933 Act never works smoothly and rationally for the small issuer. Occasionally a small issuer is able to meet the requirements of the 1933 Act without undue burden and with a reasonable degree of safety. Unfortunately, however, that is the exception and not the rule. More typically a small issuer is confronted with hyper-technical rules and interpretations that seem to have lost all contact with legitimate policy. The small company may also be faced with required procedures to which he simply cannot conform, and with pervasive vagueness that boggles the keenest legal minds.

\section{Registration and Regulation A: Excessive Costs NOT WORTH THE BENEFTTS}

Generally, neither an offering that is registered ${ }^{3}$ nor one under Regulation $\mathrm{A}^{4}$ provides an acceptable mechanism by which a small company can raise capital. Because of the cost, a full-blown registration by a small issuer desiring to sell a few thousand dollars worth of stock is impractical; the legal, accounting, printing and other miscellaneous costs associated with a registration often exceed $\$ 100,000 .^{5}$ Expenses of that magnitude would certainly make the cost of capital to the issuer greater than the projected yield of many investments.

Regulation $\mathrm{A},{ }^{6}$ however, does provide some relief in this area, since it permits sales of up to $\$ 500,000$ if the issuer files a notification with the Commission. Because the information provided in a notification is substantially less than that contained in a registration statement, the cost of preparing the offering is less. Two points must be kept in mind, however. First,

3. For a description of the registration process and the content of a registration statement, see 1 Loss $265-351$.

4. 17 C.F.R. $\$ 230.251-.263$ (1977). Regulation $A$ is not really an exemption from registration; it can be characterized instead as a simplified registration with the regional, rather than national, office of the Commission.

5. A 1970 article states: "Thus, for a typical first public issue of several hundred thousand to several million dollars, expenses between $\$ 50,000$ and $\$ 90,000$, exclusive of the underwriting discount or commission, would be common. They are rarely below $\$ 35,000$. More than $\$ 100,000$ is not uncommon, if liability insurance is purchased." Schneider \& Manko, Going PublicPractice, Procedure and Consequences, 15 VILL. L. REv. 283, 299-300 (1970). See also Schwartz 739-40. For an earlier discussion of the costs of "going public," see Wheat \& Blackstone, Guideposts for a First Public Offering, 15 Bus. Law. 539 (1960).

The Commission has proposed a simplified registration form, $\mathrm{S}-18$, which would be available for cash offerings of up to $\$ 3$ million. Securities Act Release No. 5915 (Mar. 6, 1978), [Current] FED. SEC. L. REP. (CCH) I 81,531. Although the proposed form is less extensive than the present $S-1$ form, the burden of complying with $S-18$ would still be significant, and its use would not relieve the problems described in this section.

6. 17 C.F.R. § 230.251-.263 (1977). For a discussion of Regulation A, see Glavin \& Purcell, Securities Offerings and Regulation A-Requirements and Risks, 13 Bus. LAW. 303 (1958); Weiss, Regulation A Under the Securities Act of 1933-Highways and Byways, 8 N.Y.L.F. 3 (1962). 
when smaller issues ranging from $\$ 50,000$ to $\$ 100,000$ are involved, the cost of complying with Regulation A will still be relatively substantial. ${ }^{7}$ Second, the impact of state Blue Sky laws becomes a more significant factor in a Regulation A offering. If an offering is registered under the 1933 Act, most states permit the issuer to fulfill the state registration requirements by "coordination," that is, by filing the same information that was filed with the SEC in the states where the offering is made. ${ }^{8}$ This procedure can result in significant time and cost savings to the issuer. However, coordination is generally not available if the issuer utilizes Regulation A; rather, an issuer relying on Regulation A must comply with the state's more complex and expensive" requirements for "qualification." 10 Much of the cost savings of Regulation A would thus be eradicated by the cost of complying with the qualification requirements of local state statutes. ${ }^{11}$ This problem obviously worsens as the number of states in which the securities are to be offered increases, since qualification would be required in each individual state.

It should finally be noted that this burdensome cost may not be justified by policy considerations. It is not entirely certain that significant protection will be generated by requiring a small issuer to go through the registration process. Much has been written about the ordinary prospectus' complexity and the resulting need for professionals to "filter" the information to the investor. ${ }^{12}$ Although the argument may vary slightly among commentators, the charge basically is that the complexity of a prospectus makes it incomprehensible to the average investor. Accordingly, any protection to the investor comes only if the information is "filtered" through a professional investment analyst, usually a broker-dealer. As one author has stated,

7. See Burge, Regulation A: A Review and a Look at Recent Developments, 46 L.A. B. Bull. 290, 310 (1971) (offerings under Regulation A "involve greater percentage costs in relation to the amount of securities sold").

8. See, e.g., CAL. CORP. CODE $\$ 25111$ (West 1977); Del. CODE tit. 6, § 7305 (1975); FLA. Stat. ANN. \$ 517.08 (West 1972); Ky. Rev. STAT. \$292.370 (1971); VA. CODE § 13.1-509 (1973).

9. Compare, e.g., KY. REv. STAT. $\$ 292.360$ (1971) (registration by "coordination") with KY. REv. STAT. \& 292.370 (1971) (registration by "qualification").

10. This is true in Kentucky, for example. According to the state Staff of the Division of Securities, there can be no coordination with a Regulation A offering. Other states also apparently will not permit coordination with a Regulation A offering. See note 11 infra.

11. One author has stated that "[t]here is generally no state Blue Sky Law counterpart in the Midwest to Regulation A, so full 'qualification' or 'registration' is generally required." Coles, An Introduction to Regulation A: Small Business Financing Exemption, $56 \mathrm{CHI}$. B. REC. 34, 36 (1974).

12. For contrasting views on the value of a prospectus to an average investor without professional help, compare Kripke, The SEC, the Accountants, Some Myths and Some Realities, 45 N.Y.U. L. REv. 1151, 1165 (1970) (the concept that investors may be fully informed and can reach an intelligent decision based on a prospectus termed a "delusion"), with Sowards, The Wheat Report and Reform of Federal Securities Regulation, 23 VAND. L. REv, 495, 532 (1970) (prospectus does provide investor with sufficient information to make an informed decision). 
"while the disclosure is provided for the investing public and not the financial community as such, the latter is an essential middleman in seeking out, digesting, and evaluating data that would otherwise be far too voluminous to be of real use to most investors." 13

When a small company's offering is being made, it is not likely that there will be effective filtration, since investors in small companies typically do not seek professional investment advice to aid in their evaluation of a prospectus. Furthermore, since trading in the stock of small companies is sporadic, it is not economically feasible for brokers and dealers to perform the type of analyses that are done with respect to widely traded stocks, and thus extensive professional analysis usually is not available.

This is not to say, however, that disclosures to investors in small companies would be unsound as a policy matter. At least some of the purchasers may be able to wade through a prospectus and glean some worthwhile insights into the company's prospects. Enforced disclosure also has something of a cleansing effect on the entire distribution process. Disclosure can deter the issuer from overpricing his stock and dampen the puffing that can sometimes border on material misstatement. One must be aware, however, that the absence of professional analysis lessens the effectiveness of the registration requirement.

In summary, neither registration nor compliance with Regulation $A$ is practical for most small company offerings of securities. Furthermore, the absence of an investment analyst's help, which could act as a "filter" for the information, together with the inability of the typical small company investor to read a prospectus or an offering circular, diminishes the protective value of registration.

\section{OfFerings PuRsuant to Section 4(2): The PRIVATE Placement EXEMPTION}

Section 4(2) of the 1933 Act provides an exemption from registration for "transactions by an issuer not involving any public offering." $14 \mathrm{Al}$ though this exemption has been one of the most frequently used, ${ }^{15}$ it has been the subject of extensive criticism, ${ }^{16}$ typically revolving around the section's lack of clarity. ${ }^{17}$ This criticism intensified after $S E C v$. Continental

13. Cohen, “Truth in Securities" Revisited, 79 HaRv. L. REv. 1340, 1377 (1966).

14. 15 U.S.C. $\$ 77 \mathrm{~d}(2)$ (1970).

15. See Victor \& Bedrick, Private Offering: Hazards for the Unwary, 45 VA. L. REv. 869, 869 (1959), where the authors characterize section 4(2) as "probably the most frequently used of all the exemptions, either consciously or unconsciously." See also 25 SEC, STATISTICAL Bull. No. 3, at 13 (Mar. 1966); Steffen, The Private Placement Exemption: What To Do About a Fortuitous Combination in Restraint of Trade, 30 U. CHI. L. REv. 211, 212 (1963).

16. See Section 4(2) and Statutory Law, 31 Bus. LAw 485, 505-11 (1975), for an extensive list of writings on the subject.

17. One author has characterized the exemption as "a tale of growing confusion." McDer- 
Tobacco Co. ${ }^{18}$ a case in which the Commission seemed to take the position that only "insiders" of an issuer were qualified under section 4(2) to be offerees and purchasers. ${ }^{19}$

\section{A. Exemption Through Compliance with Rule 146.}

1. The Attempt to Resolve Ambiguity. Rule $146^{20}$ was enacted by the Commission in an attempt to eliminate much of the uncertainty surrounding section $4(2)$ by providing fair, workable and understandable requirements for qualifying under that section. ${ }^{21}$ If one were to judge by the literature, however, the Commission has failed horribly. ${ }^{22}$ One commentator has gone so far as to refer to the Rule as a "major blunder." 23

Unquestionably, Rule 146 has not removed many of the major ambiguities which existed prior to the Rule. For example, although purchasers under Rule 146 are required to have "access" to information about the issuer, the term "access" is undefined. ${ }^{24}$ Likewise, the sophistication re-

mott, The Private Offering Exemption, 59 IowA L. REv. 525, 549 (1974). Another commentator has stated that "reliance on the non-public offering exemption in any financing not involving a private placement with institutional type investors is a hazardous risk." Meer, The Private Offering Exemption Under the Federal Securities Act-A Study in Administrative and Judicial Contraction, 20 Sw. L.J. 503, 534 (1966).

18. 463 F.2d 137 (5th Cir. 1972). One commentator characterized this holding as "an opinion that may serve as a model for arcane obscurity in the securities field." Schwartz 746. See also McDermott, supra note 17, at 526-40; Note, Proposed SEC Rule 146: The Quest for Objectivity, 41 FordhaM L. REv. 887, 902-07 (1973); Note, SEC v. Continental Tobacco Co. and SEC Proposed Rule 146 as Attempts to Define a Private Offering: The Insecure Exemption from Registration Under the Securities Act of 1933, 41 GEO. WASH. L. REv. 582, 588-92 (1973); Note, SEC Rules 144 and 146: Private Placements for the Few, 59 VA. L. REv. 886, 893-901 (1973).

19. Brief for Appellant at 26, 28, SEC v. Continental Tobacco Co., 463 F.2d 137 (5th Cir. 1972).

20. 17 C.F.R. \$ 230.146 (1977).

21. Securities Act Release No. 5487, at 1-4 (Apr. 23, 1974), 1 FED. SEC. L. REP. (CCH) I 2710 , at $2907-2$ to -5 .

The Commission has recently called for comment on the effectiveness of Rule 146 as a vehicle for financing by small issuers. Securities Act Release No. 5914 (Mar. 6, 1978), [Current] FED. SEC. L. REP. (CCH) I 81,530, at 80,163.

22. For criticism of Rule 146, see Kessler, Private Placement Rules 146 and $240-S a f e$ Harbor?, 44 FORDHAM L. REv. 37 (1975); Kinderman, The Private Offering Exemption: An Examination of its Availability Under and Outside Rule 146, 30 Bus.' LAw. 921 (1975); Schwartz; Weinberg \& McManus, The Private Placement Exemption Under the Securities and Exchange Act of 1933 [sic] Revisited, and Rule 146, 27 BAYLOR L. REV. 201 (1975).

23. Kripke, SEC Rule 146: A "Major Blunder", N.Y.L.J., July 5, 1974, at 1, col. 3. Another author has advocated "a major overhaul of Rule 146 with the purpose of providing greater certainty as to the rule's application." Heumann, Is SEC Rule 146 Too Subjective to Provide the Needed Predictability in Private Offerings?, 55 Neb. L. Rev. 1, 9 (1975).

24. Under Rule 146, each offeree, during the course of the transaction and prior to sale, must either have "access" to the same kind of information that would be found in a registration statement or the issuer must supply the offeree with that information. In a note accompanying the Rule, the Commission states that "[a]ccess can only exist by reason of the offeree's position with respect to the issuer. Position means an employment or family relationship or 
quirement, which dictates that the purchaser have "such knowledge and experience in financial and business matters that he is capable of evaluating the merits and risks of the prospective investment," 25 is a concept that will be difficult to apply in certain instances. ${ }^{26}$ Since there has been extensive and respectable comment on these problems, it would be unproductive to restate those problems and analyses here. ${ }^{27}$

What has not been discussed adequately, however, is the especially burdensome impact these ambiguities have on small issuers. Although the ambiguities of Rule 146 are unquestionably irritating to larger issuers, economic realities generally make the containment of the risk from ambiguity significantly more difficult for the small issuer than for the larger company. Comparatively limited options and lack of flexibility may make it impossible for a small company to take the steps necessary to reduce the ambiguity to a manageable level.

The disadvantages of the small corporation are very apparent when it must deal with the ambiguity of the "access" requirement of Rule $146 .{ }^{28}$ The easiest way for an issuer to meet the "access" requirement is by making offers only to persons that have "[a]ccess . . . by reason of . . . [their] position with respect to the issuer."29 In that instance it is not necessary for the issuer to underwrite the extensive costs of supplying information to the offerees, since it is assumed that the offeree's position enables him to obtain necessary information. This concept of access by reason of position is so limited and ambiguous, ${ }^{30}$ however, that some steps

economic bargaining power that enables the offeree to obtain information from the issuer in order to evaluate the merits and risks of the prospective investment." 17 C.F.R. $\$ 230.146(e)$ (note) (1977).

Whether a particular offeree has access by reason of his position is a question that has troubled a number of commentators. See, e.g. , Weinberg \& McManus, supra note 22, at 231. In fact, one commentator has stated that the "test [for access] is so vague that the only safe course for the issuer is to furnish the information." Kessler, supra note 22, at 67.

25. 17 C.F.R. \$ 230.146(d) (1977).

26. See Kinderman, supra note 22 , at 928 ; Schwartz 760.

27. See Heumann, supra note 23, at 7; Kessler, supra note 22, at 67 ; Schwartz 760; Weinberg \& McManus, supra note 22, at 231.

28. Dealing with the uncertainty in other areas of Rule 146 also may be more onerous for the small corporation than the large. For example, if an issuer has some doubt about the wealth or the sophistication of potential offerees, risk can be contained by not offering the Rule 146 stock to the doubtful offeree. Although this may be irritating to the large issuer, larger issuers will usually have alternative of ferees and thus can more easily contain the risk by elimination of doubtful offerees. Smaller issuers, however, generally seem to have fewer options and thus the elimination of offerees to contain the risk becomes more costly and can threaten the success of the offering. Simply stated, elimination of an offeree for an issuer that wants to build a supermarket in a small town may have a more significant impact than elimination of an offeree for a $\$ 50$ million corporation whose stock is traded over the counter.

29. 17 C.F.R. $\$ 230.146$ (e) (note) (1977).

30. Under Rule 146, there are three types of entities that are deemed to have access: entities with access through employment, entities with access through family relationships, and 
usually must be taken to reduce the uncertainty to a manageable level. It is in reducing this ambiguity that the larger issuer has a substantial advantage over the smaller issuer.

Any issuer that is uncertain as to whether the potential offerees have access by reason of position can reduce the risk of this ambiguity by supplying the offerees with certain information. Realistically, the larger issuer may more easily comply with this requirement of supplied access, since the Rule provides a simple and inexpensive method for larger issuers to meet the access requirements. The Rule provides that any large company that is reporting under the Securities Exchange Act of $1934^{31}$ can meet the access requirements by supplying all offerees with the company's latest annual report, any definitive proxy statement required to be filed and any other documents filed with the Commission since the filing of the annual report. ${ }^{32}$ The access requirements for smaller, non-reporting companies are much more burdensome, however, since they are required to supply the same information that would be contained in a registration statement. ${ }^{33}$

Obviously, small issuers will rarely be reporting under the Securities Exchange Act of $1934^{34}$ and therefore cannot provide access by the simpler method of supplying the annual reports and other documents. They are instead required to go through the extremely burdensome procedure of gathering and disclosing the same information that would be contained in a registration statement. ${ }^{35}$ It is thus much more difficult for a small, non-

entities with access through economic bargaining power. The rule is unclear, however, as to what types of employment or family relationships satisfy its test. Further, since there is a significant amount of risk in assuming that a particular person who is not an institutional investor has economic bargaining power, only insiders and relatives of the issuer would remain as practical offerees by virtue of their position.

31. Under section 12 of the Securities Exchange Act of 1934, a company is required to register any class of securities that is registered on any national exchange, 15 U.S.C. $\$ 78 l(a)$ (1970), or any class of equity securities held by 500 or more shareholders, where the company has assets in excess of $\$ 1$ million. $I d . \$ 78 /(\mathrm{g})(1)$. Once a company has registered stock under the $1934 \mathrm{Act}$, it is required to make periodic disclosures to the Commission. $I d$. $\$ 78 \mathrm{~m}$. Thus it is referred to as a "reporting company."

32. 17 C.F.R. $\$ 230.146(\mathrm{e})(1)(\mathrm{a})(1977)$.

33. Id. $\S 230.146(\mathrm{e})(1)(\mathrm{b})$.

34. Although it is possible for any company to register under the 1934 Act, 15 U.S.C. $\$ 78 l$ (1970), companies generally do not register voluntarily because of the costs involved in registering and reporting.

35. Another problem for the small issuer in meeting the access requirement results from the position of the Commission staff that the issuer must, in addition to providing to offerees the information normally contained in a registration statement, furnish the offerees with an opportunity to verify the accuracy of the information. 17 C.F.R. $\$ 146(\mathrm{e})(2)$ (1977). This position of the Commission staff seems to result from their feeling that there must be some review process present to perform the function normally provided by the Commission staff's scrutiny of an issuer's statements regarding a registered offering. While the verification function provided by the Commission staff is certainly valuable and one whose presence in some form for any offering may arguably be beneficial, the verification requirement of Rule 146 adds to the cost of compliance and makes compliance a more cumbersome procedure. It could also be argued that 
reporting issuer to reduce the ambiguity of the access requirement than it is for the larger company reporting under the 1934 Act.

Even if the larger issuer is not reporting under the 1934 Act, the burden of reducing ambiguity by supplying access often will be less on the large issuer that is involved in a substantial financing arrangement, because these larger companies are likely to have larger capital requirements and thus are likely to sell more stock in a Rule 146 offering. This means that cost as a percentage of the total yield of the offering will be less for the larger offering. The poison to financing arrangements is not the absolute cost but rather the cost as a percentage of the ultimate yield of the particular undertaking. Therefore, if a company is utilizing Rule 146 to place $\$ 5$ million in common stock, it would be much less burdened by legal costs of $\$ 25,000$ than would a company selling $\$ 75,000$ in common stock. To the extent that a small company is raising a limited amount of money by selling under Rule 146, it may be economically impossible to supply access and thus limit the uncertainty in the access concept. The cost of supplying access may well be prohibitive. ${ }^{36}$

Other burdensome effects of the Rule's ambiguity, however, result from an attempt to comply with the "sophistication requirement." It is crucial for the issuer to be certain about the sophistication of each offeree, because unless the issuer can document that every offeree was qualified, a purchaser may compel rescission notwithstanding the fact that he himself is qualified ${ }^{37}$ This potential disaster will cause an issuer to take great pains to investigate fully each potential offeree and to document carefully the investigation. For the small issuer, however, who has limited capital needs and thus may be selling a small amount of stock, the cost of such an investigation may be relatively expensive. This may contribute to the practical unavailability of Rule 146 for the small issuer. ${ }^{38}$

in light of the volume of information scanned annually by the Commission staff, their review may be characterized as cursory and one that can be performed ably by a sophisticated investor as defined in Rule 146. Indeed, that may be the rationale of the access requirement.

In the Commission's release soliciting comments on small issuers, the Commission specifically called for comment on how it should provide for disclosure under Rule 146 for nonreporting companies. Securities Act Release No. 5914 (Mar. 6, 1978), [Current] FED. SEC. L. REP. (CCH) I 81,530, at 80,163 (Question 64).

36. The author's experience has been that attorneys typically budget at least $\$ 10,000$ to $\$ 20,000$ for the legal expenses associated with supplying access to offerees. This can obviously vary, however, as hourly rates or complexity of the particular offering differ.

37. Henderson v. Hayden, Stone, Inc., 461 F.2d 1069, 1071-72 (5th Cir. 1972).

38. In a recent denial of a request for a no action letter, the Commission indicated that the prohibition against general advertising would be violated if an issuer made written solicitations of names of qualified offerees from any person. Letter from SEC Division of Corporate Finance to Arthur M. Borden, Esq. (Aug. 15, 1977), [1977-1978 Transfer Binder] FED. SEC. L. REP. (CCH) I 81,344. Although the basis of this denial was somewhat technical and the limits of the opinion are not clear, it is possible that it could have a significant impact on the ability of issuers to utilize intermediaries in placing a Rule 146 offering. This will exacerbate the difficulty that the small issuer has finding sophisticated offerees. 
In summary, ambiguities impede the effectiveness of Rule 146 for all issuers and are especially devastating to small issuers. The small issuer is often caught in the unfortunate position of being forced either to assume unreasonable risk, underwrite unreasonable costs, or, more typically, forego the utilization of Rule 146.

2. The Effect of Prior Illegal Offers and Sales. The ability of a small issuer to avoid registration under the 1933 Act is often affected by prior actions of the company taken without sound legal advice. This is principally due to two factors: first, small issuers often act without first consulting their attorneys; and second, even if counsel is consulted, the advice received may be inadequate, since counsel for small issuers tend to be relatively unsophisticated in securities matters. All too often such counsel is a generalist with limited knowledge and experience in the securities area. $^{39}$

This is not to say that every small issuer is reckless in its actions and is represented by a legal simpleton. To the contrary, many small issuers are extremely cautious and are represented by sophisticated counsel. However, in a substantial (perhaps a majority) of instances in which an existing small issuer wants to sell stock, prior uncounseled acts by the issuer generate significant problems. With monotonous frequency, a securities lawyer dealing with a small company for the first time is faced with the following situation: The issuer has decided it would like to sell stock to a limited number of persons. The problem seems to fit neatly under an available exemption until one distressing fact is learned-that, within the last year, a small amount of stock was offered or sold which, the attorney is convinced, was not in compliance with an available exemption under the 1933 Act. This then raises the problem of whether the prior illegal offers and sales will contaminate the proposed offering. ${ }^{40}$

In order to avoid registration under the securities laws, an entire issue must comply with a single exemption of the 1933 Act. Thus, for example, an issuer cannot place one-half of a single issue under the private placement exemption $^{41}$ and one-half of the issue under the intrastate exemption; 42

39. It is relevant to note that the problem of contamination by prior offers and sales can and does arise with larger corporations. Generally, however, the sophistication of the management and counsel of the larger corporation minimizes the possibility of this problem. In addition, the greater amounts of money involved encourage extensive consultation of counsel, since the cost of such services are relatively less expensive. Thus, as a practical matter, the problem of prior illegal offers and sales is most troublesome to the smaller, less sophisticated issuer.

40. Even if the prior sales were legal, the integration concept can cause problems for an issuer desiring to make another offering. If the prior offering and the proposed offering are a single issue, then both must qualify for a single exemption. Accordingly, even a prior legal offer can limit the alternatives available to the issuer.

4I. 15 U.S.C. $\$ 77 \mathrm{~d}(2)(1970)$.

42. Id. $\$ 77 \mathrm{c}(\mathrm{a})(11)$. See text accompanying notes $124-52$ infra for a discussion of the small issuer's problems in using this exemption. 
instead, the two offerings must be integrated ${ }^{43}$ and treated as a single issue, so that all sales then qualify for one or the other exemption. Similarly, if a proposed issue is integrated with prior illegal offers or sales, the proposed offers would likewise be illegal.

A small company that has made an illegal offer or sale theoretically has two avenues available that would avoid this disastrous effect. One alternative is to "undo" or neutralize the legal impact of the former offers and sales. One possible neutralizing procedure, a rescission offer by the issuer, is the subject of an article by Professor Bromberg. ${ }^{44}$ It would appear, however, that a rescission offer by the issuer is an inappropriate remedy for several reasons. First, Professor Bromberg discloses that the SEC generally requires registration of the rescission offer, although he argues that this position of the Commission is probably untenable and contrary to the trend among courts. ${ }^{45}$ As discussed earlier, the cost of registration makes it an unacceptable alternative for a small issuer.

In addition, another disadvantage of using a rescission offer is the uncertainty of its legal impact. Although Professor Bromberg considers only whether a rescission offer is effective to cut off liabilities for past violations, his conclusion is instructive. Absent an acceptance by the offeree, Bromberg opines that it is uncertain whether a rescission offer will cut off liabilities. ${ }^{46}$ While the impact of a rescission offer as a way to neutralize prior offers or sales is not discussed by Professor Bromberg, no basis exists to believe that it would be effective to throttle the contamination effect of the prior illegal offer. Certainly there is no authority in the I933 Act for such an assumption.

Because there is apparently no way to "undo" the illegal offering, the attorney for the issuer is faced with the second alternative, that of attempting to separate the former offering and the future offering into two issues. In this situation, the attorney for the issuer might hope to use the "safe harbor" provision of Rule $146,{ }^{47}$ assuming that the prior issue was made more than six months previous to the contemplated offering. Under section (b)(1) of Rule 146 , however, offerings are automatically separated only if the previous offering was made "pursuant to the exemptions provided by Section 3 or Section 4(2) of the Act." 48 The use of the word "pursuant" seems to mean "in compliance with," and it has been so interpreted by commentators. ${ }^{49}$ Since illegal offers and sales would of course not have been made in

43. For a discussion of the integration concept, see 1 Loss 575-80, 591-96, 674-76.

44. Bromberg, Curing Securities Violations: Rescission Offers and Other Techniques, $1 \mathrm{~J}$. CORP. L. 1 (1975).

45. Id. 36.

46. Id. $38-48$.

47. 17 C.F.R. \& 230.146 (b)(1) (1977).

48. Id. (emphasis added).

49. See, e.g., Kinderman, supra note 22 , at 935 . The best discussion of the integration 
compliance with an available exemption, the safe harbor provision would be inapplicable, and the integration question would be determined under traditional integration rules.

As to sales made within six months of the Rule 146 offering, the Rule ${ }^{50}$ and the notes accompanying it ${ }^{51}$ indicate that separation of the issues in this situation would also depend on traditional integration notions. ${ }^{52}$ Therefore, if an issuer has made prior illegal offers or sales at any time, the safe harbor provision of Rule 146 will not provide automatic nonintegration of the two issues. An issuer is instead relegated to traditional integration analysis in order to determine whether there are one or two issues involved.

Application of traditional integration analysis makes the judgment as to whether there are one or two issues difficult, and therefore reliance on it is dangerous for an issuer. Preliminary Note 3 to Rule 146 explicates the five factors that "should be considered" 53 in that determination:

(a) whether the offerings are part of a single plan of financing;

(b) whether the offerings involve issuance of the same class of security;

(c) whether the offerings are made at or about the same time;

(d) whether the same type of consideration is to be received; and

(e) whether the offerings are made for the same general purpose. ${ }^{54}$

Of the five factors listed, two factors will nearly always be present-the same type of consideration will normally be received and the offerings will be made at or about the same time. However, it is uncertain whether the presence of these two factors alone is sufficient to cause integration or whether additional factors must be present. Professor Loss has taken the position that separate issues can be established either by separate classes of stock or separate plans of financing. ${ }^{55}$ This approach would provide some flexibility for an issuer since an issuer could meet the "separate classes" requirement if the two offerings involved securities with substantially different contractual rights. Loss warns, however, that "the differences must be substantial.",56

Unfortunately, however, the Commission apparently does not accept

concept is found in an article analyzing Rule 147, which has a provision identical to the one in Rule 146. Hicks 469-77.

50. 17 C.F.R. $\$ 230.146(b)$ (1977).

51. Id. \$230.146 (preliminary note 3 ).

52. See Hicks 474-77.

53. 17 C.F.R. $\$ 230.146$ (preliminary note 3) (1977).

54. Id.

55. 1 Loss 577-78.

56. Id. 578. The idea that separate classes or separate plans of financing will be sufficient to establish separate issues is also found in an early Commission release. See Securities Act Release No. 2029 (Aug. 8, 1939), 1 FED. SEC. L. REP. (CCH) I 2,140. See also 17 C.F.R. 230.146 (preliminary note 3) (1977). 
Professor Loss' opinion that separate classes can effectively separate two offerings of securities. In fact, Preliminary Note 3 to Rule 146 apparently is inconsistent with Professor Loss' position, since it describes separate classes as only one of the "factors [that] should be considered." 57 This lack of clarity has caused one author to observe that "there is insufficient guidance available to permit an informed judgment as to how the concept would be applied in many factual circumstances that are likely to arise." 58

The Commission has apparently developed one rule of thumb which provides some clarity in this area, although it is of little help to many issuers. The position of the Commission seems to be that a one year delay may be sufficient to ensure separate issues of stock..$^{59}$ The problem, of course, is that in many instances the issuer will be unwilling or perhaps literally unable to wait for that length of time.

The result of all these problems is an unfortunate one for many small issuers, since the application of the integration concept may result in the foreclosure of an issuer from utilization of Rule 146 for a period of one year from the prior illegal offers or sales. This is especially unfair in light of the fact that those prior illegal offers are often made with the advice of counsel who has failed properly to advise the issuer concerning the 1933 Act. It is difficult to believe that the Commission would sanction such a result if it were aware of the problem. However, the Commission, preoccupied with central markets and $S-1 \mathrm{~s},{ }^{60}$ has in fact failed to devote adequate resources and attention to the special problems of small issuers in this area.

3. Resale of Restricted Securities Pursuant to Rule 144. Although the problems caused by a prior illegal offer or sale are significant and often render Rule 146 unavailable to a small issuer, those problems are neither as pervasive nor as devastating as the problems created by the restrictions on the resale of stock taken in a Rule 146 offering. Simply stated, the restrictions on resale of stock taken in a Rule 146 offering are so onerous that it is difficult or impossible for an issuer to find purchasers who are willing to live with the resale restrictions. Accordingly, although Rule 146 is theoretically available for use by a small issuer, the practicalities of the situation make use of the Rule difficult, since the purchaser of the securities must be willing both to hold his securities for at least five years and to sell what may be an unreasonably small amount of the securities each year. ${ }^{61}$

57. 17 C.F.R. $\$ 230.146$ (preliminary note 3) (1977).

58. Kinderman, supra note 22, at 923.

59. Goldman, The Intrastate Offering, in NEw TRENDS AND SPECIAL PROBLEMS UNDER THE SeCuRITIES LaW 173, 182 (A. Sommer ed. 1972).

60. The $S-1$ form is filed with the Commission when registration is contemplated for a commercial or industrial issuer.

61. See notes 83-96 infra and accompanying text.

In the Commission's release soliciting comments on small issuers, the Commission specifi- 
The most obvious mechanism available for the resale of stock taken in a Rule 146 offering is Rule $144,{ }^{62}$ but unfortunately it is almost impossible for Rule 144 to be utilized by an investor in a small issuer ${ }^{63}$ One reason for this is the requirement in Rule 144 that there "be available adequate current public information with respect to the issuer." 64 For a large corporation that is reporting under the 1934 Act, meeting the public information requirement is simple, since mere compliance with the periodic reporting requirements is sufficient. ${ }^{65}$ On the other hand, it is not at all clear whether or how a nonreporting company, especially one that is small and not widely traded, can ensure that there is "available adequate current public information." 66

Although the Commission has provided some indication as to how a non-reporting company can meet the public information requirement, this attempt at guidance has not clarified the requirement adequately for the small issuer. The Commission has found that information about a nonreporting issuer was "publicly available" only where periodic reports had been supplied to shareholders, recognized financial services and interested dealers and marketmakers. ${ }^{67}$ It would seem to be very difficult for a small issuer to meet the spirit of these requirements for several reasons. First, financial reporting services are not usually interested in smaller issuers and there will probably be no dealer making a market in the stock. In addition, general dealer interest will be slight or nonexistent with respect to the stock. Accordingly, it is uncertain how or whether a small issuer can meet the public information requirement of Rule $144 .{ }^{68}$

cally called for comment on the extent to which restrictions on resales affect the usefulness of Rule 146. Securities Act Release No. 5914 (Mar. 6, 1978), [Current] FED. SEC. L. REP. (CCH) I 81,530 , at 80,163 (Question 67).

62. 17 C.F.R. $\$ 230.144$ (1977). For a discussion of the resale problem prior to Rule 144, see Miller \& Seltzer, The SEC's New Rule 144, 27 Bus. LAw. 1047, 1047-49 (1972); Sommer, Considerations Leading to the Adoption of Rule 144, 67 Nw. U.L. REv. 65 (Supp. 1972).

63. It appears that most commentators regard Rule 144 as a success. See, e.g., Lipton, Fogelson \& Warnken, Rule 144-A Summary Review After Two Years, 29 Bus. LAw. 1183, 1183 (1974); Sommer, supra note 62, at 73.

64. 17 C.F.R. $\$ 230.144(c)(1977)$.

65. Id. $\$ 230.144(\mathrm{c})(1)$. Most corporations not presently required to file under the 1934 Act would not wish to file voluntarily, since compliance with the reporting requirements would entail great expense and effort.

66. This problem has perplexed commentators, leading one to state that Rule 144 furnished little guidance regarding what constitutes public availability. This was felt to be not a lapse on the part of the draftsmen but rather the result of a combination of reliance on common law techniques and a desire to encourage voluntary reporting. See Applebaun, The Rule 144 Pattern-An Overview, 67 Nw. U.L. REv. 76, 80 (Supp. 1972).

67. Securities Act Release No. 5306, at 8 (Sept. 26, 1972), 1 FED. SEC. L. ReP. (CCH) I 2705F, at 2,813-15.

68. Commentators seem to take different positions concerning the exclusivity of the method explicated in Securities Act Release No. 5306, supra note 67. One author seems to believe that small issuers have some flexibility in meeting all the requirements of the release ("it seems safe to conclude that sending such information periodically to the issuer's stockholders 
Even this lack of certainty, however, is not the major obstacle to the utilization of Rule 144 by the investor in a small issuer. ${ }^{69}$ The seemingly insurmountable obstacle is rather the limitation on the manner of sale imposed by the Rule. Under Rule 144, sales can be made only in 'brokers' transactions," 70 which is defined to prohibit any "solicitation of orders to buy the securities." 71 There is an exception to the prohibition against solicitation in the situation where a selling broker makes "inquiries . . . of other brokers or dealers who have indicated an interest in the securities within the preceding 60 days." In the case of widely traded securities, it is possible for the selling broker to comply with Rule 144 because there typically will be indications of interest in the stock from marketmakers and other interested dealers. ${ }^{72}$ Therefore, although the resale provisions of Rule 144 restrict the selling efforts of brokers selling the stock of larger companies, the Rule is not prohibitive for those issuers.

In the case of the small issuer, however, this limitation on selling effort by the seller and his broker cannot be complied with, thereby foreclosing investors in small issuers from the use of Rule 144 to sell their stock. ${ }^{73}$ Since there is by definition ${ }^{74}$ no active market in the stock of a small issuer, it will be impossible for the original purchaser of the restricted securities to resell

will suffice"). Miller \& Seltzer, supra note 62, at 1054. Another commentator states, however, that "[u]nless those guidelines can be fully complied with, it would seem advisable for a broker handling a transaction under Rule $144(\mathrm{c})(2)$ to obtain an interpretation from the SEC staff before proceeding with the sale." Rissman, Rule 144: Manner of Sale and Availability of Public Information, 67 Nw. U.L. REv. 124, 134 (Supp. 1972).

69. There is also one other major obstacle to the use of Rule 144 by the investor in a small company. That obstacle results from the amount requirement, which limits sales under Rule 144 to "one percent of the securities . . . of the class outstanding" during any six month period. 17 C.F.R. $\$ 230.144$ (e) (1977). In a small corporation, perhaps one with only $\$ 100,000$ in assets and one hundred shares of stock, the limit of one percent every six months would permit a shareholder to sell only $\$ 2,000$ worth of stock every year. Not only are there possible problems in selling such small amounts of stock, but more importantly, a shareholder with $\$ 10,000$ in stock would be unable to liquidate for years. This problem will be considered in greater detail in the context of Rule 237 at text accompanying notes 83-87 infra.

70. 17 C.F.R. $\$ 230.144(f)$ (1977).

71. Id.

72. For a description of the over-the-counter market, see I. COBLEIGH, THE 1971 ENCYCLOPEdia OF STOCK MARKet TEChNIQUES 98-103 (1970); V. HARPER, HANDBOOK OF INVESTMENT Products ANd Services 5-7 (1975); Reach, The Over-the-Counter Market, in THE STOCK MARKET HANDBOOK 167-75 (F. Zarb \& G. Kerekes eds. 1970); Cappucci, Over-the-Counter Trading, in THE STOCK MARKET HANDBOOK, supra at 540-53.

73. One author has described the problems faced by small firms with only a few marketmakers as follows:

Rule 144 will be of limited practical significance to the holders of restricted securities in . . many smaller companies whose securities are traded only in the over-thecounter market. Under the Rule brokers for these security holders can attempt to sell to the few market makers who appear or recently appeared in the "sheets" (or in the NASDAQ system) for the security.

Miller \& Seltzer, supra note 62 , at 1061 .

74. See note 2 supra. 
the stock in "brokers' transactions." In the first place, most brokers would refuse to accept the sell order for such stock because it would be uneconomical for a broker to attempt to find a buyer for the stock. ${ }^{75}$ Even if a broker did accept the sell order it would be impossible to abide by the Rule 144 prohibition against the solicitation of offers to buy. Because of the absence of an organized market in the stock, it is unlikely that there would be prior indications of interest in the stock that are known to the selling broker. Consequently, it would be impossible for the selling broker to sell the stock without solicitation of offers to buy. Obviously such solicitation would not comport with the requirements of Rule 144.

In summary, the resale of restricted securities in small issuers cannot be made pursuant to Rule 144 . This is due principally to the fact that the holder of the restricted securities cannot comply with the requirement that the sales be made only in "brokers' transactions."

Other alternatives for the resale of restricted securities provide little relief for small issuers. For example, prior to the adoption of Rule 144 there was a body of law that allowed the sale of restricted securities in certain situations. ${ }^{76}$ Stated in its broadest terms this "common law" of resale generally enabled the staff of the Commission to grant a no-action letter when stock had been held for three years or more. ${ }^{77}$ Additionally, the "change of circumstances" doctrine was available, permitting the resale of restricted securities at any time if the investor could demonstrate a change in his circumstances that made the proposed resale consistent with an initial investment intent. In these situations the holder of the restricted securities was held not to have taken with a view to distribution. ${ }^{78}$ Although the Commission stated in the preliminary notes to Rule 144 that the Rule was not the exclusive method for selling restricted securities, ${ }^{79}$ it so muddled the prior common law that such law was practically repealed. The Commission effected this by stating that persons selling outside the Rule "will have a substantial burden of proof in establishing" that the resales are legal. Additionally, the Commission stated that "the staff will not issue no-action letters relating to resales of such securities" and that "the "change in circumstances' concept should no longer be considered as one of the factors

75. The author talked with two brokers, both of whom said that it was usually not economically feasible to receive sell orders for stock in such small issuers.

76. For a discussion of the law applicable to the resale of securities as it existed prior to Rule 144, see the Wheat Report SEC Disclosure Group, Securities and Exchange Commission, Disclosure to InVestors-A Reappraisal of Federal Administrative POLICIES UNDER THE '33 AND ' 34 ACTS 160-77 (CCH ed. 1969).

77. See Sommer, supra note 62, at 69-72.

78. 1 Loss 665-73; Sommer, supra note 62, at 70. Had the investor taken the shares with "a view toward distribution" he would be an "underwriter," requiring registration of the stock prior to any sale by him.

79. 17 C.F.R. \& 230.144 (preliminary note) (1977). 
in determining whether a person is an underwriter." The Commission went on to point out that "the fact that securities have been held for a particular period of time does not by itself establish the availability of an exemption." 80

The practical effect of these pronouncements is to make Rule 144 exclusive, ${ }^{81}$ since all the understandable common law has been stripped away. If the securities have been held by a client for five years, perhaps some attorneys would be willing to say that resale is permissible under the common law doctrine. Even after that extensive holding period, however, it is not clear that resale would be consistent with an initial investment intent. 82

This leaves, then, only Rule $237^{83}$ as a mechanism by which one holding restricted securities in a small company can resell those securities. ${ }^{84}$ Under the terms of this Rule, an investor holding restricted securities can resell during any twelve month period "the lesser of the gross proceeds from the sale of 1 percent of the securities of the class outstanding or $\$ 50,000$ in aggregate gross proceeds." 85 Furthermore, the stock must have been held for five years ${ }^{86}$ and can be sold only "in negotiated transactions otherwise than through a broker or dealer." 87

One problem is that Rule 237 is not available to "an affiliate of such issuer." 88 Since an affiliate includes a person who controls an issuer, ${ }^{89}$ Rule 237 would not be available to an investor attempting to resell restricted securities if that investor were deemed to have a control relationship with the small issuer. Although it is beyond the scope of this Article to discuss in

80. Securities Act Release No. 5223 (Jan. 11, 1972), [1971-1972 Transfer Binder] FED. SEC. L. REP. (CCH) 178,487 .

81. See Note, Rule 144: SEC Regulation of Disposition of Securities by Controlling Persons and Private Placements, 25 VAND. L. Rev. 845, 883 (1972).

82. Lipton, Fogelson \& Warnken, supra note 63, at 1198 , states:

In view of the strong policy statement of the SEC in Release No. 5223 . . . , it would appear that counsel may render favorable opinions as to sales outside the Rule of post-144 restricted securities only in very limited situations-those where the issuer is a major listed company, the amount can be sold readily without material effect on the market . . . and there has been a holding period substantially more than two years (probably in the area of three to five years). Substantially the same standards are applicable to pre-144 restricted securities, except that the current three-year holding period is generally considered adequate. Most lawyers will not give an opinion in either situation where the company is marginal or the amount of securities cannot be readily absorbed by the normal trading market, no matter what the holding period.

83. 17 C.F.R. $\$ 230.237$ (1977).

84. One student author has theorized that Rule 237 was an attempt by the Commission "to avoid unduly restricting the liquidity of these investments." Note, supra note 81 , at 886.

85. 17 C.F.R. $\$ 230.237$ (b) (1977).

86. Id. $\S 230.237(\mathrm{a})(3)$.

87. Id. $\$ 230.237(\mathrm{a})(4)$.

88. Id. $\S 230.237(2)$.

89. Rule 237 states that "the definition contained in . . . $\$ 230.405$ shall apply to the terms in this section." Id. $\$ 230.237$ (d). Rule 405 defines "Affiliate" to include "a person that . . . controls . . . the person specified." Id. $\S 230.405$. 
detail the concept of control under the 1933 Act, ${ }^{90}$ it is important to note that control does not require the ownership of fifty-one percent of the stock of the corporation. ${ }^{91}$ Rather, courts and the Commission have found control where there is substantially less ownership, ${ }^{92}$ and it has even been said that ten percent ownership of a company may be sufficient to find control under the 1933 Act. ${ }^{93}$ Additionally, it appears that a significant management position or an established relationship with a large shareholder can also be a basis for control. ${ }^{94}$

In light of this, Rule 237 may be unavailable for many investors in small issuers. Since they often own in excess of ten percent of the company's stock and also share some management responsibilities, they may be considered an "affiliate" within the meaning of the Rule and thus excluded from its protection. There may be good policy reasons for not allowing a person in control of a large issuer to resell restricted securities under Rule 237. It could be argued, for instance, that such a person would be likely to possess influence over the issuer sufficient to force the filing of a registration statement. The unfairness to a small issuer, however, results from two sources: first, the Rule's definition of "control"' includes most, if not all, of a small issuer's shareholders, who own large percentages of stock not because of an intent to resell but because the total capital invested is small; and second, despite the assumption that the influence alone of a "control" person can force registration, the costs associated with that alternative make registration financially impractical for a small sale of stock. ${ }^{95}$ It should also be noted that even if such a control person agreed to indemnify the issuer against all liability and to pay the cost of a registration statement, the small issuer would still bear a substantial burden in virtually having to shut down its business operations during the statement's waiting and effective periods. ${ }^{96}$

A final problem with Rule 237 is that even if investors in small

90. See Campbell, Defining Control in Secondary Distribution, 18 B.C. INDus. \& Com. L. REv. 37 (1976).

91. Id. $41-42$.

92. For example, in In re Thompson Ross Securities Co., 6 S.E.C. 1111 (1940), the Commission found control where the shareholder owned only $18 \%$ of the voting stock.

93. See Enstam \& Kamen, Control and the Institutional Investor, 23 Bus. LAw. 289, 315 (1968); Sommer, Who's 'in Control?"-S.E.C., 21 Bus. Law. 559, 568 (1966). It even has been suggested by one commentator that $5 \%$ is the relevant figure. S.E.C. PROBLEMS OF CONTROLLiNG Stockholders AND IN UNDERWRitings 19 (C. Israels ed. 1962) (statement of Mr. B. Kohlman).

94. See Campbell, supra note 90 , at 44-49.

95. See text accompanying notes 5-13 supra.

96. This virtual shutdown results from the Act's requirement that all material events or changes in the issuer's financial condition occurring after filing of the statement with the Commission, but prior to the effective date, be reflected in amendments to the registration statement. Securities Act of 1933, §§ 8(a), 11, 15 U.S.C. $\S \S 77 \mathrm{~h}(\mathrm{a}), 77 \mathrm{k}$ (1970). 
companies are not control persons, the required holding period and the limitation on the amount of stock that can be sold under the Rule makes resales difficult. This problem can best be demonstrated by an example. Assume that a promoter wishes to start a corporation in which he will invest $\$ 50,000$, and five other persons including Mr. Adams will put up $\$ 10,000$ each. The initial offering will qualify for an exemption under Rule 146. Under Rule 237, Mr. Adams could make no sales for five years, and even then he could sell only a maximum of stock worth $\$ 1,000$ per year, since that value is one percent of the value of the securities outstanding. Consequently, Mr. Adams could not liquidate his investment for fourteen years, an unreasonably long holding period that most investors would find unacceptable. Because of these unnecessarily rigid provisions, Rule 237 is of marginal benefit to a small company that wishes to make an initial offering under Rule 146. The restriction on resale is so burdensome that it may be difficult to find initial investors for the securities.

It is difficult to measure the impact of these resale problems, but they are most likely to be significant to the small issuer. As a practical matter, it is difficult for a small issuer attempting to comply with the initial requirement for a private placement to find offerees who have the sophistication or the wealth to be qualified offerees under Rule 146. To add to that situation the requirement that the offerees be willing to hold the securities for half a lifetime places Rule 146 outside the category of usable exemptions for many small issuers.

4. Cost of Compliance. Finally, the cost of complying with Rule 146 can effectively foreclose a small issuer from utilizing that exemption. One problem arises because of the procedure that must be followed to ensure that the offerees are qualified within the meaning of Rule $146 .{ }^{97}$ Normally, this will necessitate time-consuming investigation and evaluation of the offerees and their offeree representatives in order reasonably to determine whether they are wealthy or sophisticated..$^{98}$

Furthermore, the availability of due diligence defenses adds to the expense of complying with Rule 146. Because an offer to an unqualified person will not destroy the availability of Rule 146 if the issuer can bear the burden of proving that he reasonably believed the offeree to be qualified, ${ }^{99}$ it is incumbent on the issuer (and his attorney) to keep accurate records in the

97. Under Rule 146, an issuer can make offers only to persons that either are "capable of evaluating the merits and risks of the prospective investment" or "able to bear the economic risk of the investment." 17 C.F.R. \& 230.146(d) (1977).

98. For a discussion of the type of investigations that are appropriate in connection with a Rule 146 offering, see Green \& Wittner, Private Placement of Securities Under Rule 146, 21 PRAC. LAW. 9 (1975). See text accompanying notes 36-38 supra for a discussion of the effect upon small issuers of required compliance with these procedures.

99. 17 C.F.R. \& 230.146(d) (1977). 
area of offeree qualification. These records must show the issuer's reasonable judgment in deciding that the offerees were qualified. This recordmaking contributes further to costs. ${ }^{100}$

The major expense, however, is caused by the "access" requirement of Rule 146. Typically, this will necessitate an undertaking by the small issuer to supply each offeree with the same information that would be contained in a registration statement, ${ }^{101}$ and as a result the legal and accounting expense becomes significant. Because of the expense incurred in collecting and disseminating this information, a small issuer proposing to sell a small amount of stock will be practically foreclosed from using Rule 146. In very general terms, it would be unusual for an offering of less than $\$ 100,000$ to be suitable for Rule 146 treatment, since the legal fees of complying with Rule 146 and supplying the access required under that Rule could exceed $\$ 20,000 .^{102}$

\section{B. Private Placement Outside of Rule 146.}

Prior to the adoption of Rule 146, a substantial amount of common law had developed under section 4(2). ${ }^{103}$ Although Rule 146 may have made the common law of private placement less important, the Commission in adopting Rule 146 emphasized that the Rule did not repeal the common law under section $4(2){ }^{104}$ This position of the Commission, together with dissatisfaction over Rule 146, has contributed to a rekindling of interest in section 4(2)

100. For a discussion of appropriate documentation, see Green \& Wittner, supra note 98.

101. Under Rule 146 access can either be supplied by the issuer or be implied from the position of the offerees. The latter form of access, however, is limited to "employment or family relationship or economic bargaining power that enables the offeree to obtain information from the issuer in order to evaluate the merits and risks of the prospective investment." 17 C.F.R. \$230.146(e)(note) (1977). Because of the limited nature of this exemption, it is normally necessary for the issuer to supply access. See text accompanying notes 28-35 supra. One writer has stated that the "test [for access] is so vague that the only safe course for the issuer is to furnish the information." Kessler, supra note 22, at 67.

102. Obviously this can vary with the hourly rates of the lawyers involved or the complexity of the offering. The figure of $\$ 20,000$ is based on personal experience and information supplied by other lawyers. For a comparison with the costs of registration, see note 5 supra.

103. See SEC v. Ralston Purina Co., 346 U.S. 119 (1953); Parvin v. Davis Oil Co., 524 F.2d 112 (9th Cir. 1975); Woolf v. S.D. Cohn \& Co., 515 F.2d 591 (5th Cir. 1975); SEC v. Continental Tobacco Co., 463 F.2d 137 (Sth Cir. 1972); Hill York Corp. v. American Int'l Franchises, Inc., 448 F.2d 680 (5th Cir. 1971); Lively v. Hirschfeld, 440 F.2d 631 (10th Cir. 1971); Gilbert v. Nixon, 429 F.2d 348 (10th Cir. 1970); United States v. Custer Channel Wing Corp., 376 F.2d 675 (4th Cir.), cert. denied 389 U.S. 850 (1967); Garfield v. Strain, 320 F.2d 116 (10th Cir. 1963); Woodward v. Wright, 266 F.2d 108 (10th Cir. 1959); Haber v. Bordas, [1975-1976 Transfer Binder] FED. SEC. L. REP. (CCH) I 95,330 (S.D.N.Y. 1975); SEC v. Universal Major Indus. Corp., [1975-1976 Transfer Binder] FED. SEC. L. REP. (CCH) I 95,229 (S.D.N.Y. 1975); Livens v. William D. Witter, Inc., 374 F. Supp. 1104 (D. Mass. 1974); Securities Act Release No. 285 (Jan. 24, 1935), I FED. SEC. L. REP. (CCH) II 2740-2744. For other cases, releases and articles dealing with the section 4(2) exemption, see Section 4(2) and Statutory Law, supra note 16, at 505-13.

104. Securities Act Release No. 5487 (Apr. 23, 1974), I FEd. SEC. L. REP. (CCH) I 2710. 
in the last year or so. ${ }^{105}$ Despite the intellectual and practical interest in section 4(2), utilization of this section by a small company is made difficult by the same factors that make Rule 146 impractical for the small issuer.

1. Ambiguities Encountered in Complying with Section 4(2). The ambiguity problem is probably more intense in section $4(2)$ than in Rule 146. 106 Under Rule 146, the norms are at least explicit, although the application of those norms can be quite baffling. Thus, for example, it is clear under Rule 146 that some offerees must be able to bear the economic risk of the investment. Uncertainty arises only in the determination of whether a particular offeree has the wealth to meet that norm. Under section $4(2)$, however, it is not even clear that wealth is a criterion for the availability of that exemption. ${ }^{107}$ It is also unclear whether an outsider can be qualified as an offeree under section 4(2) even if his lack of access to information is relieved by the issuer's voluntary supplying of information to the offeree. Although the present trend seems to indicate that such supplied access is sufficient under section $4(2),{ }^{108}$ there is language to the contrary in certain cases. ${ }^{109}$

In short, ambiguity is a significant problem under section $4(2)$ and in fact was one reason the Commission promulgated Rule 146. The problem for the small issuer is essentially the same as that discussed earlier in connection with Rule $146 .{ }^{110}$ It is difficult for the small issuer to limit the risk of section $4(2)$, because the cost incurred in so containing the risk may make the alternative prohibitively expensive. Alternatively, failure to take

105. See, e.g., Institutional Private Placements Under the Section 4(2) Exemption of the Securities Act of 1933, 31 Bus. LAw. 515 (1975) [Paper of the Committee on Developments in Business Financing, Section of Corporation, Banking and Business Law of the American Bar Association); Section 4(2) and Statutory Law, supra note 16 (Position Paper of the Federal Regulation of Securities Committee, Section of Corporation, Banking and Business Law of the American Bar Association).

106. See McDermott, supra note 17, at 549; Meer, supra note 17 , at 534 . It is interesting to note that former SEC Chairman Garrett once stated that the common law under section 4(2) was "a kind of mishmash. The issuer is now told that all of these factors have something to do with whether he has an exemption under section $4(2)$, but he is never given a hint as to the proper proportion in the brew." Garrett, The Private Offering Exemption Today, in FourTH AnNual Institute on Securities Regulation 3, 10-11 (R. Mundheim, A. Fleischer \& J. Schupper eds. 1973).

107. For a discussion of the requirements of section 4(2), see Schneider, Section 4(2) and "Statutory Law," in Sixth ANNUAL InSTITUTE on SECuRITIES REgulation 157, 163-89 (R. Mundheim, A. Fleiseher, J. Schupper, J. Jewett \& J. Thomson eds. 1975); Section 4(2) and Statutory Law, supra note 16.

108. See, e.g., Doran v. Petroleum Management Corp., 545 F.2d 893 (5th Cir. 1977). This seems to be the position of most commentators. See, e.g., Schwartz 762.

109. See SEC v. Continental Tobacco Co., 463 F.2d 137, 160 (5th Cir. 1972); Hill York v. American Int'1 Franchises, Inc., 448 F.2d 680, 688 n.5 (5th Cir. 1971).

110. See notes 20-60 supra and accompanying text. See also Securities Act Release No. 5487, at 1-4 (Apr. 23, 1974), I FED. SEC. L. REP. (CCH) T 2710, at 2907-2 to -5. 
steps to limit the ambiguity of the section leaves the risk at a dangerously high level.

2. The Effect of Potential Integration. Contamination caused by prior illegal offers or sales can also cause section $4(2)$ to be unavailable, ${ }^{111}$ at least for a significant period of time. As described earlier, the application of the integration concept may cause prior illegal offers and sales made by the issuer to be considered part of the same issue as the proposed offering under section 4(2). This would, of course, destroy the availability of section $4(2)$, since the prior illegal offers would prevent the entire offering from qualifying for a single exemption. ${ }^{112}$

Since there is no safe harbor provision applicable to section $4(2),{ }^{113}$ the determination of whether the issues will be integrated depends on the traditional integration factors, which have been discussed previously in this Article. ${ }^{114}$ It is sufficient to recall at this point that the uncertainty in the application of those factors often makes an effective separation of the offerings doubtful. Therefore, in order to comply with the informal position of the Commission, a small issuer may be forced to wait one year from the last offering in order to separate effectively the prior illegal offering. ${ }^{115}$

Alternatively, if an issuer makes a section 4(2) offering within one year of the prior, illegal offering, he does so at the risk that the integration concept will cause the prior offering to be integrated with the later offering, in which case the entire issue would not qualify for section 4(2) treatment. Obviously, neither the one year delay nor the assumption of the risk of earlier sales presents an attractive alternative for an issuer.

3. Restriction Upon Resale. Utilization of section 4(2) generates the same resale problems found in Rule 146 offerings. ${ }^{16}$ Stated in broad terms, a public resale by one who purchases under section $4(2)$ is inconsistent with the nonpublic nature of the exemption and thus can be made only if there is an exemption available for the resale. ${ }^{117}$ Unfortunately, none

111. For a discussion of the contamination effect on Rule 146 offerings, see text accompanying notes 39-58 supra.

112. For a discussion of the integration concept as it applies to private placements under section 4(2), see 1 Loss 575-80, 591-96, 674-75.

113. Under Rule 146, sales made more than six months prior to an offering under Rule 146 will not be integrated with the sales under Rule 146 if the prior sales were made "pursuant to" an available exemption. 17 C.F.R. $\$ 230.146(b)(1)$ (1977).

114. See text accompanying notes 53-59 supra. See also Securities Act Release No. 4552, at 4-5 (Nov. 6, 1972), 1 FED. SEC. L. ReP. (CCH) I 2781, at 2921.

115. See Goldman, supra note 59, at 173, 182.

116. See text accompanying notes 61-96 supra.

117. More precisely, one who purchases in a private placement but who has an intent to resell and does resell publicly would become an underwriter and thus subject to the registration requirements of the 1933 Act. 15 U.S.C. $\$ 77 b(11)$ (1970). In such a situation, the entire transaction, including both the original sale by the issuer and the resale by the first purchaser, 
of the exemptions available for the resale of those restricted securities is satisfactory for the owner of securities in the small corporation.

As described earlier in this Article, Rule 144 is generally not available for resales of restricted securities of a small issuer, principally because it is impossible to comply with the requirement that all sales must be made in "brokers' transactions." 118 It is similarly impossible to make sales outside Rule 144, because the Commission effectively repealed the "common law" of resales that existed prior to the adoption of Rule $144 .{ }^{119}$

Accordingly, one who holds restricted securities in a small company is relegated to Rule 237 , and that Rule is not a satisfactory resolution of the resale problem. As described earlier, the restrictions are so burdensome that many investors will forego an investment in a small issuer in order to avoid tying up capital for the decade or so necessary to comply with the Rule. ${ }^{120}$

4. Costs Incurred in Compliance with Section 4(2). It is difficult to specify the cost of complying with section 4(2), since the elements of section 4(2) qualification are somewhat ambiguous. ${ }^{121}$ Notwithstanding that difficulty, however, it now appears that qualification for section 4(2) probably requires certain characteristics of the offerees and some disclosure of information by the issuer to the offerees. Meeting these requirements will generate significant costs to the issuer and may, in fact, make section 4(2) an unattractive alternative for avoiding registration.

At the present time, section 4(2) offerings probably should be limited to persons who are financially sophisticated, ${ }^{122}$ and indeed a strong argument can be made that offerees under section 4(2) should possess both sophistication and wealth. ${ }^{123}$ In any event, any requirement with respect to

would be viewed as part of a single transaction, which would no longer be deemed a transaction "by an issuer not involving any public offering." For a discussion of this problem, see 1 Loss 665-73; Wheat Report SEC Disclosure Group, supra note 76, at 160-77.

118. See text accompanying notes $69-72$ supra.

119. See text accompanying notes 76-82 supra.

120. See text accompanying notes $83-96$ supra.

121. See, e.g., Garrett, supra note 106 , at $10-11$.

122. See, e.g., Schwartz 761. One significant article, however, indicates that sophistication is not always required in order for section 4(2) to be available. The article states that the offeree qualification requirement can be met by offerees having other characteristics, such as wealth or relationship to the issuer. Section 4(2) and Statutory Law supra note 16, at 491. Serious doubts can be entertained, however, about the soundness of that position, and in fact the above article hedges on the proposition. The article states: "We might have serious reservations about including a very wealthy person as an offeree in a highly risky private placement based solely upon his ability to assume the risk, if he had no understanding of financial matters, and no competent advisor." Id.

123. Although it is not clear that compliance with section 4(2) requires that all of ferees be both wealthy and sophisticated, see note 122 supra, practical considerations should make an attorney reluctant to approve offerees that do not possess both characteristics. If investors do possess these characteristics, they become generally analogous to institutional investors, who probably are the safest offerees for an issuer seeking to comply with section 4(2). See generally 
the characteristics of offerees will necessitate the gathering and evaluation of information about those offerees, and that necessarily results in added expenses for the issuer. ${ }^{124}$

Under section 4(2), it also now appears that the requirement that all offerees have access to information can be satisfied by the issuer's supplying information to the offerees and purchasers. ${ }^{125}$ The exact extent of the disclosures that must be made, however, is not certain. Although there are risks in disclosing substantially less information than what would be contained in a registration statement, ${ }^{126}$ some have argued that the disclosure requirements under section 4(2) are not nearly as extensive as those of a registration statement. ${ }^{127}$ Still, even if one takes the position that the less extensive disclosures are required, this gathering and rendering of information may place the cost of complying with section 4(2) beyond the means of small issuers, especially when one adds the burden of investigating offeree qualifications.

In summary, if the issuer proposes to sell stock only to persons who are actively engaged in the management of the corporation or if the proposed offering is to four persons who are starting a business together and will all be involved in the running of the enterprise, the cost of utilizing section 4(2) probably will not be unreasonable. In that situation, the need to investigate the characteristics of the offerees will be minimal, since the offerees will be known to the issuer. Furthermore, disclosure to those insiders will not be necessary, since their positions will give each access to all relevant information. In the more typical situation, however, where the issuer proposes to sell securities to ten persons, eight of whom are persons outside the manage-

Institutional Private Placements Under the Section 4(2) Exemption of the Securities Act of 1933, supra note 105.

124. Under section 4(2), there are no "due diligence" defenses, that is, an issuer cannot avoid liability by revealing documentation of a good faith effort to comply. Therefore, there may be less need to document the efforts involved in investigating offeree characteristics and thus less cost in complying with section $4(2)$ in this area. Since lawyers have been sued in this area, however, it may be sound for each attorney to keep records proving that he was not negligent with respect to the judgment that each offeree was qualified.

125. See, e.g., Doran v. Petroleum Management Corp., 545 F.2d 893 (5th Cir. 1977). This seems to be the position of most commentators also. See, e.g., Schwartz 769-72. There is some language in certain cases that indicates to the contrary, however. See SEC v. Continental Tobacco Co., 463 F.2d 137, 160 (5th Cir. 1972); Hill York v. American Int'l Franchises, Inc., 448 F.2d 680, 688 n.5 (5th Cir. 1971).

126. See, e.g., Wolf v. S.D. Cohn \& Co., 515 F.2d 591, 612-13 (5th Cir. 1975).

127. There is substantial opinion that section $4(2)$ can be satisfied by substantially less information than is contained in a registration statement. See Section 4(2) and Statutory Law, supra note 16, at 496 . Such opinion is influenced by the provisions of Rule 146 which permit the access requirement to be satisfied by disclosures that are less extensive than the information contained in a registration statement, but only if, "under the circumstances, the omitted information is not material." 17 C.F.R. $\S 230.146(e)(1)(b)(1)$ (1977). While Rule 146 standards are not necessarily coextensive with section $4(2)$, they do seem to reflect the underlying policy of section $4(2)$. 
ment structure of the corporation, the cost of compliance with section 4(2) will be substantial. Investigations of the qualifications of offerees and the disclosure of relevant information will inflate costs to the point that small offerings by small issuers will become prohibitively expensive.

\section{EXEMPTION FROM REgISTRATION By COMPLIANCE WITH RULE 240}

Rule $240^{128}$ provides an exemption from registration for stock sales of up to $\$ 100,000$ per year, provided that the issuer has no more than 100 security holders. ${ }^{129}$ In adopting this Rule the Commission stated that it was intended to provide an exemption for small issuers in instances "where, because of the small size and limited character of the offering, the public benefits of registration are too remote." 130 In fact, the Rule does minimize or eliminate many of the problems that plague small issuers in qualifying for other exemptions. ${ }^{131}$ Unfortunately, the Commission did not eliminate the problems caused by unreasonable restrictions on resale, and consequently the effectiveness of the Rule is significantly diminished.

\section{A. Reduction of Ambiguity.}

On the positive side, Rule 240 mitigates the ambiguity problem often present with other exemptions. Since the Rule contains no nebulous concepts such as "sophistication," "ability to bear the economic risk" or "access," 132 the practical availability of Rule 240 is not hampered by the risk and extra legal expense that accompany the use of other exemptions. This advantage over the other exemptions makes Rule 240 the most appealing alternative of those available to a small issuer.

\section{B. Contamination by Prior Illegal Offers and Sales.}

Another problem that also is minimized by the Rule is the contamination effect that can result from prior offers and sales by the issuer. Rule 240 contains its own concept of integration, and under that concept each sale

128. 17 C.F.R. \& 230.240 (1977).

129. Rule 240 contains other requirements that must be met. Under section (c), for example, there is a prohibition against general advertising. Section (d) prohibits the payment of remuneration for solicitation services, and section (g) places restrictions on resales. Finally, section (h) requires a notice of the use of the exemption to be filed by the issuer with the Regional Office of the Commission. Id.

130. Securities Act Release No. 5560, at 1 (Jan. 24, 1975), [1974-1975 Transfer Binder] FED. SEC. L. REP. (CCH) 180,066 , at 84,945 .

131. For a discussion of Rule 240 , see Note, ,Federal Deregulation of Small Issues of Securities: Rule 240, 27 ME. L. REv. 347 (1975).

In its release calling for an examination of the effects of the securities acts on small issuers, the Commission solicited comments on Rule 240. Securities Act Release No. 5914 (Mar. 6, 1978), [Current] FED. SEC. L. REP. (CCH) $\$ 81,530$, at 80,162.

132. These are concepts from Rule 146. See text accompanying notes 24-38 supra. 
under the Rule stands or falls on its own facts. ${ }^{133}$ The illegality of prior or subsequent offers or sales therefore does not destroy the availability of Rule 240 , so long as all the requirements of Rule 240 were met for the particular sale which an issuer seeks to bring within the Rule. For example, if on June 1,1977 a sale is made that does not meet the requirements of Rule 240 , and on June 2 a sale is made that does meet the requirements of Rule 240 , the June 2 sale is not contaminated by the prior sale. So long as on June 2 there are no more than 100 shareholders of the issuer and there has been no more than $\$ 100,000$ sold in the last twelve months, the exemption will be available, even though under traditional integration concepts both sales would be considered part of a single offering, and therefore both would be illegal.

This is not to say, however, that all prior offers and sales are irrelevant to the availability of Rule 240 . Obviously, prior sales can affect the availability of Rule 240 to an issuer, since prior sales must be considered in calculating the $\$ 100,000$ limitation upon sales within the prior twelvemonth period. Additionally, Rule 240 makes it clear that the special integration concept applies only for determining the availability of Rule 240 and does not protect offerings made in reliance on other exemptions. ${ }^{134}$ Accordingly, a prior, legal sale made in reliance on an exemption other than Rule 240 could be contaminated by a subsequent offer under Rule 240. Again, an example may make this clearer. If a sale of stock is made on June 1 to certain investors under the intrastate exemption ${ }^{135}$ and another sale is made on September 1 under Rule 240, the traditional integration concepts would apply to the intrastate offering on June 1, notwithstanding that the special integration concepts of Rule 240 would protect the September 1 offering. Thus, although the September 1 offering may be legal itself, that offering may have to be integrated into the June 1 offering in order to determine the availability of the intrastate exemption. This means that if any of the offerees of the September 1 offering were out-of-state residents, the June 1 offering would not meet the requirements for the intrastate exemption.

In at least one other instance, prior offers or sales by an issuer can have an additional impact on the availability of Rule 240 . This particular problem involves the Rule's prohibition against "general advertising,"136 and it

133. 17 C.F.R. $\$ 230.240$ (b)(note) (1977). The Release states that

each individual transaction effected in reliance on the rule must meet all the terms and conditions of the rule; the availability of the rule will not be affected by other transactions effected in reliance on the rule but which do not meet all its terms and conditions. However, all such transactions must be considered in determining the availability of other exemptions for other offers or sales of unregistered securities.

Securities Act Release No. 5560, at 2 (Jan. 24, 1975), [1974-1975 Transfer Binder] FED. SEC. L. REP. (CCH) $¥ 80,066$, at 84,948 .

134. 17 C.F.R. $\$ 230.240$ (preliminary note 6) (1977).

135. See text accompanying notes 144-72 infra for a discussion of this exemption.

136. This concept of "general advertising" found in Rule 240 is a nebulous one which is not 
occurs in the not unusual situation where the issuer has engaged in some sales promotion for its securities prior to the Rule 240 offering. That particular sales activity may constitute a violation of section (c) of the Rule, which prohibits offers or sales "in reliance on this rule by any means of general advertising or general solicitation." 137 If the prior activity could be characterized as general advertising, it is conceivable that the advertising would be considered an attempt to boost sales in the Rule 240 offering. The Rule itself provides no remedy for a violation of this kind, nor does it explain how these particular illegal acts affect future use of the Rule. All the Rule provides is that all conditions of the Rule must be met, and that there can be no general advertising under the Rule. The Rule therefore does not explain whether general advertising on January 1, 1977 would be considered as part of a sale on July 1, 1977 and thus contaminate the availability of Rule 240 for the July sale.

Notwithstanding these particular uncertainties, however, the value of the special integration provision of Rule 240 should not be overlooked. Clearly that concept resolves a significant problem for small issuers, and it does so in a fair manner. In determining the impact of prior offers and sales on the availability of Rule 240, the small issuer now has an understandable norm that does not unreasonably foreclose the availability of the exemption.

\section{Reduced Costs.}

Perhaps one of the most attractive aspects of Rule 240 is the small cost to the issuer incurred in complying with the exemption. Since no investigation of offeree characteristics is required, ${ }^{138}$ and since there is no requirement that the issuer make any disclosures to the offerees, ${ }^{139}$ the legal (and other) fees that the issuer must bear are minimal. In fact, of all the exemptions normally available to a small issuer, compliance with Rule 240 is the least expensive.

\section{Restriction Upon Resale.}

Unfortunately, the attractiveness of Rule 240 is significantly limited by restrictive resale requirements. Section (g) of Rule 240 states that securities

defined by the Rule. 17 C.F.R. $\$ 230.146$ (c) (1977). The same terms are used in Rule 146, but it is unclear whether the definitions are the same.

137. 17 C.F.R. $\$ 230.240$ (c) (1977).

138. Under Rule 146, it will usually be necessary for the issuer to make reasonable investigation in order to ensure that the offerees are either wealthy or sophisticated. See text accompanying notes $97-100$ supra. Similarly, it also is necessary under the intrastate exemption of Rule 147 to make investigation to ensure that all offerees are residents of the same state as the issuer. See text accompanying note 166 infra.

139. Under Rule 146 , it is usually necessary for the issuer to supply offerees with the same information that is contained in a registration statement. See text accompanying notes 34-38 supra. 
taken in a Rule 240 transaction "shall be deemed to have the same status as if they had been acquired in a transaction pursuant to section 4(2) of the Act." 140 Consequently, the same resale restrictions that apply to securities taken under Rule 146 and section 4(2) apply to resales of securities taken under Rule 240. Accordingly, it normally will be impossible for an investor to resell these restricted securities for at least five years, since the only practical method of resale available is through Rule $237^{141}$ and not Rule $144^{142}$ or the "common law" of resales. ${ }^{143}$

The impact of these resale restrictions on the availability of Rule 240 is significant: the issuer is forced to find investors that are willing to hold the securities for at least five years and probably much longer. As a practical matter this can have a devastating effect on the sale of securities, since investors are generally unwilling to commit capital for such an extended period of time.

\section{E. Summary of Rule 240 as an Alternative to Registration.}

Rule 240 eliminates many of the impediments that make qualification for other exemptions difficult. The ambiguities related to compliance are minimal, the contamination problem is manageable and the cost of compliance is reasonable. One serious and pervasive problem remains, however, and that is the problem caused by unreasonable restrictions on resale. It is unfortunate that the Commission has permitted this problem to taint an otherwise attractive exemption for small issuers.

\section{INTRASTATE OFFERINGS BY SMALl ISSUERS: SECTION 3(A) AND RULE 147}

\section{A. Exemption Under Section 3(a)(11).}

Section $3(a)(11)$ of the 1933 Act, ${ }^{144}$ the intrastate exemption, provides an exemption from registration for offers and sales made to residents of the same state in which the issuer is incorporated and doing business. ${ }^{145}$ Prior to

140. 17 C.F.R. $\$ 230.240(\mathrm{~g})$ (1977). In the Commission's release soliciting comments on small issuers, the Commission specifically called for comment on the extent to which restrictions on resale affect the usefulness of Rule 240. Securities Act Release No. 5914 (Mar. 6, 1978, [Current] FED. SEC. L. REP. (CCH) I 81,530, at 80,162 (Question 58).

141. See text accompanying notes 83-96 supra.

142. While the two-year holding period of Rule 144 is much shorter than the five-year requirement of Rule 237, Rule 144 allows an investor to sell only in "brokers' transactions," with no solicitation allowed. The problems which this requirement creates for the investor in a small issuer are discussed in text accompanying notes 61-75 supra.

143. See text accompanying notes 76-82 supra.

144. 15 U.S.C. $\$ 77 \mathrm{c}(\mathrm{a})(11)(1970)$.

145. More specifically, the section exempts from registration

[a]ny security which is a part of an issue offered and sold only to persons resident within a single State or Territory, where the issuer of such security is a person resident 
the adoption of Rule 147, the intrastate exemption had fallen into a state of practical uselessness. Because of confused and unreasonably strict interpretations, it generally was impossible for an issuer to comply with section $3(a)(11)$, at least with any degree of security. ${ }^{146}$

It was uncertain, for example, how much of an issuer's operations had to be conducted in a particular state in order for that issuer to be "doing business" in that state. ${ }^{147}$ Additionally, the residency requirement for the offerees was a source of uncertainty, since it had been interpreted to mean "domicile."148 As a result of that interpretation, the issuer had to make a judgment about the subjective state of mind of all offerees, since domicile required physical presence as well as an intent to remain. ${ }^{149}$ Finally, the

and doing business within or, of a corporation, incorporated by and doing business within, such State or Territory.

Id.

The philosophical underpinning for section 3(a)(11) is not entirely clear. One author has stated:

The following reasons have been offered from time to time in support of the intrastate exemption: (1) In terms of economic policy, it is useful to allow securities offerings by a small businessman to his friends, relatives, business associates, and others, without federal restrictions; (2) registration for such small offerings would, as a practical matter, be almost impossible; (3) investors in local financings are protected by the sanctions of public opinion; (4) such investors are protected by their proximity to the issuer; (5) such investors are protected by state regulation; and (6) intrastate offerings do not present questions of national interest. Hicks 499.

146. One article indicated that " $[\mathrm{b}]$ ecause of these risks, major underwriters have adopted a general policy of refusing to participate in intrastate offerings." Alberg \& Lybecker, New SEC Rules 146 and 147: The Nonpublic and Intrastate Offering Exemptions from Registration for the Sale of Securities, 74 Colum. L. Rev. 622, 648 (1974).

It is interesting to note that, notwithstanding the massive problems associated with section 3(a)(11), "there are indications of the offer and sale of a substantial volume of securities to the investing public under color of the intrastate exemption." HOUSE COMM. ON INTERSTATE \& Foreign CoMmerce, Report of Special Study of Securities Markets of the Securities and ExChange Commission, H.R. Doc. No. 95, 88th Cong., 1st Sess., pt. 1, at $572-73$ (1963).

147. In 1961 the Commission stated that the "doing business" requirement "can only be satisfied by the performance of substantial operational activities in the state of incorporation." Securities Act Release No. 4434 (Dec. 6, 1961), I FED. Sec. L. Rep. (CCH) IT 2270, 2273. Professor Loss has opined that "[p]erhaps-although this is far less clear-the issuer may even be doing the major part of its business elsewhere" and still qualify under 3(a)(11). 1 Loss 601 . Finally, one author has reviewed the no-action letters from the staff of the Commission and concluded that "the SEC staff has regularly insisted that at least eighty percent of the issuer's business exist in and continue within the state." Hicks 480 .

148. 1 Loss 598-99; Alberg \& Lybecker, supra note 146, at 645-46.

149. See Securities Act Release No. 4434, at 3 (Dec. 6, 1961), 1 FED. SEC. L. REP. (CCH) $\pi$ 2274, at 2609. The classic cases involving this interpretation have involved military personnel, who have been held not to be residents of the states in which they are stationed. SEC v. Capital Funds, Inc., SEC Litigation Release No. 1805 (D. Alaska 1960), noted in Securities Act Release No. 4434, 1 FED. SEC. L. REP. (CCH) חा 2270, 2274; SEC v. Big Top, Inc., SEC Litigation Release No. 2756 (D. Nev. 1963).

For a discussion of the concept of domicile, see R. WeinTRAub, Commentary on the CONFLICT OF LAWS 8-16 (1971). In Mitchell v. United States, 88 U.S. (21 Wall.) 350, 352 (1874) the Supreme Court defined the state of mind necessary to establish domicile as "the intent to remain for an unlimited time." 
Commission had declared that the stock sold under the intrastate exemption must "come to rest" in the hands of residents of the same state in which the issuer was doing business before any resale or re-offer of the stock could be made by the original purchasers. ${ }^{150}$ Not only was there some confusion about how long stock must be held before it "came to rest," 151 but there also was uncertainty concerning the power or ability of the issuer to prevent the original purchasers from making re-offers that would contaminate the original offering. This question was critical because the issuer could not prevent a purchaser qualifying under the exemption from re-offering his stock to a nonresident, an act that apparently contaminated the entire offering. ${ }^{152}$

Because of this uncontrollable risk and unacceptable level of ambiguity, the intrastate exemption was virtually useless to a corporation attempting to avoid the pains of registration under the 1933 Act. One commentator stated that it was "extremely dangerous to rely upon the exemption except under almost laboratory conditions," 153 and that characterization may have been overly generous. Accordingly, although the Commission has taken care to emphasize that Rule 147 does not repeal the common law of section 3(a)(11), the high level of uncontrollable risk causes the exemption to be an unrealistic alternative for a small issuer wishing to raise capital by selling stock.

\section{B. The Intrastate Exemption as Modified by Rule 147.}

Effective March 1, 1974 the Commission adopted Rule $147^{154}$ and thereby resolved many of the problems inherent in the intrastate exemption. By defining some key terms in section 3(a)(11), the Commission seems to have successfully throttled the unmanageable risk of the intrastate exemp-

150. Securities Act Release No. 4434 (Dec. 6, 1961), 1 FED. SEC. L. REP. (CCH) IT 2270 , 2271.

151. The position of the Commission seems to be that the stock "comes to rest" after one year. Hicks 488. See also Emens \& Thomas, The Intrastate Exemption of the Securities Act of 1933 in 1971, 40 U. CIN. L. REv. 779, 786-87 (1971); Kant, SEC Rule 147-A Further Narrowing of the Intrastate Offering Exemption, 30 Bus. LAW. 73, 91-93 (1974).

152. Controlling resale does not present an insoluble problem, since restrictive legends on securities and stop-transfer orders with transfer agents can effectively throttle sales. See Israels, Stop Transfer Procedures and the Securities Act of 1933-Addendum to Uniform Commercial Code-Article 8, 17 RUTGERS L. REv. 158 (1962). It is not clear, however, that legends and stop-transfer orders will effectively prevent illegal re-offers by persons purchasing in a section 3(a)(I1) transaction. Although these restrictive devices may make the actual transfer of the stock impossible, the offer may destroy the exemption. See Hicks 488.

153. Kant, supra note 151, at 74-75. Another author has stated that the statutory exemption was "Ioaded with dynamite." Gadsby, The Securities Exchange Commission and the Financing of Small Businesses, 14 Bus. LAw. 144, 148 (1958).

154. Securities Act Release No. 5450 (Jan. 7, 1974), [1974-1975 Transfer Binder] FED. SEC. L. REP. (CCH) I 79,617 . 
tion. ${ }^{155}$ Rule 147 makes the intrastate exemption an attractive alternative for small issuers if the issuer can satisfy his capital requirements by tapping only the intrastate market.

1. Ambiguities Eliminated by the Rule. The Rule eliminates one significant ambiguity by rejecting domicile as the applicable norm for the offeree's residence. Instead, an offeree is qualified under Rule 147 if the state of his "principal residence" 156 is the same as that of the issuer. In addition, the Commission has taken care to declare that the subjective state of mind of the offeree is not relevant to determining "principal residence." 157 Unfortunately, however, the issuer is forced to be a "guarantor" of the fact that all of the offerees are indeed residents of the state. Even if the issuer exercises due care in his investigation, the fact that one offeree is in reality the resident of another state can destroy the exemption for the entire offering.

The requirement that the issuer be "doing business" in the state also has been clarified, although it perhaps is this definition that now contains the most uncertainty. The Rule requires that the issuer derive eighty percent of its gross revenues from a business located in the state, that eighty percent of the issuer's assets be located in the state, that eighty percent of the proceeds from the offering be used in connection with the business operation in the state and that the principal office of the issuer be located in the state. ${ }^{158}$

One criticism that has been leveled against this definition is that it is too restrictive. It is claimed that the eighty percent requirements will unnecessarily restrict the availability of the intrastate exemption, ${ }^{159}$ since few issuers

155. Some commentators disagree. See Alberg \& Lybecker, supra note 146, at 649-54, where the authors discuss some of the remaining uncertainty associated with the integration concepts of Rule 147. The Commission has recently called for comment on the effectiveness of Rule 147 as a vehicle for financing by small issuers. Securities Act Release No. 5914 (Mar. 6, 1978, [Current] FED. SEC. L. REP. (CCH) I 81,530, at 80,160.

156. As initially proposed, the Rule required that offerees, in order to be a "resident" of a state, must have their principal place of residence within the state and have no present intention of moving that residence. Securities Act Release No. 5349, at 11 (Jan. 8, 1973), [1972-1973 Transfer Binder] FED. SEC. L. REP. (CCH) I 79,168, at 82,549. Since the purpose of the Rule was to eliminate needless uncertainty, the Commission, in adopting the final Rule, eliminated the requirement that offerees have no present intention of moving. 17 C.F.R. $\$ 230.147$ (d)(2) (1977). The Commission stated that this was done because "it would be difficult to determine a person's intentions." Securities Act Release No. 5450, at 8 (Jan. 7, 1974), [1973-1974 Transfer Binder] FED. SEC. L. REP. (CCH) I 79,617, at 83,653.

157. The intentions of the offerees are not completely irrelevant, however. Although principal place of residence is the norm stated in the Rule itself, the release accompanying the Rule states: "Temporary residence, such as that of many persons in the military service would not satisfy the provisions of paragraph (d)." Securities Act Release No. 5450, at 8 (Jan. 7, 1974), [1973-1974 Transfer Binder] FED. SEC. L. REP. (CCH) ๆ 79,617, at 83,653. For a rcconciliation of this apparent conflict, see Hicks 483-87.

158. 17 C.F.R. $\$ 230.147$ (c)(2) (1977).

159. Kant, supra note 151 , at 75 . 
will be able to demonstrate those characteristics. It is not clear, however, that the eighty percent requirements cause the Rule to be more restrictive than the Commission's interpretations under section 3(a)(11). In fact, one author has reviewed the no-action letters the Commission issued under section 3(a)(11) prior to the adoption of Rule 147 and concluded that "the SEC staff has regularly insisted that at least eighty percent of the issuer's business exist in and continue within the state. "160 It therefore appears that Rule 147 essentially codified the informal position of the Commission and did not cause the intrastate exemption to become more restrictive.

A second problem with the "doing business" requirement of Rule 147 is that there is uncertainty remaining in the concept, notwithstanding the attempt by the Commission to quantify the requirement. For example, the requirement that eighty percent of the revenues of the issuer must be derived from the "operation of a business . . . within such state" can be especially troublesome in situations where the manufacture or distribution of a firm's products involves any significant contact with other states. Would a company be deriving eighty percent of its revenues from the "operation of a business" in State $A$ if eighty percent of its manufacturing were done in State $A$, twenty percent in State $B$, and ninety percent of all sales were made by salesmen in states other than $A$ or $B$ ? One should not overemphasize the marginal uncertainty inherent in the "doing business" requirement, however. By quantifying the requirement and by issuing releases $^{161}$ and rulings ${ }^{162}$ interpreting the requirement, the ambiguity problem has been significantly mitigated. ${ }^{163}$

2. Restrictions on Resale. The provisions regarding the resale of securities taken in a Rule 147 transaction are both clear and fair. The Rule prohibits resales to nonresidents for nine months; thereafter, however, the securities have "come to rest" and resales can be made with impunity. 164 Additionally, the Commission states in the release accompanying the adoption of the Rule that re-offers to nonresidents within the nine-month holding

160. Hicks 480 .

161. In the release accompanying the adoption of Rule 147 the Commission treated five hypothetical situations under Rule 147. By so doing, the Commission clarified somewhat the concept of "doing business." Securities Act Release No. 5450, at 7 (Jan. 7, 1974), [1973-1974 Transfer Binder] FED. SEC. L. REP. $(\mathrm{CCH})$ I 79,617, at 83,652-53.

162. ICF Ins. Co., SEC. REg. \& L. REP. (BNA) No. 386, at C-2 (Jan. 19, 1977); Dennis A. Rosen, SEC. REG. \& L. REP. (BNA) No. 385, at C-1 (Jan. 12, 1977).

163. As evidence of that, this author would cite his own experience in advising issuers (and issuers' lawyers) about the availability of certain exemptions. Since the adoption of Rule 147, this author has worked on approximately ten proposed offerings in which Rule 147 was considered as an alternative. The "doing business" requirement was troublesome only in one or two of those proposed transactions. In the other eight or nine situations, it was clear whether or not the requirement was met.

164. 17 C.F.R. $\$ 230.147(\mathrm{e})$ (1977). 
period do not destroy the availability of Rule $147 .{ }^{165}$

Obviously, this is an attractive provision from the point of view of investors and the original issuer. Unlike securities taken in private placements or under Rule 240 , the resale provisions are not so onerous as to dampen the investment zeal of purchasers. Further, Rule 147 is a definite improvement over section 3(a)(11), since it now is clear how long the securities must be held and that re-offers to nonresidents will not destroy the exemption.

3. The Cost of Complying with Rule 147. One of the most attractive aspects of Rule 147 is the comparatively low cost of qualifying for the exemption. The issuer is not required to make any disclosure of information to the offerees, and thus a Rule 147 offering is significantly less expensive than Rule 146, Regulation A, or registration. Furthermore, no significant investigation of the offerees' characteristics is required, since the only characteristic the offeree must possess is that of having his residence in the same state as the state in which the issuer is doing business. Judging the residence of offerees typically requires only a minimum of investigation and documentation, and therefore a minimum of expense. As a result, the costs of qualifying for Rule 147 generally will be at a manageable level for an issuer, ${ }^{166}$ although costs of course vary depending on the risk or complexity of the particular offering.

165. Securities Act Release No. 5450 (Jan. 7, 1974), [1973-1974 Transfer Binder] FED. SEC. L. REP. (CCH) $\uparrow 79,617$, at 83,653 . As initially proposed, however, the Rule did prohibit resales and re-offers for a period of 12 months. Securities Act Release No. 5349, at 11 (Jan. 8, 1973), [1972-1973 Transfer Binder] FED. SEC. L. REP. (CCH) \ 79,168 at 82,549.

There is one conceptual problem that deserves mention. It is clear that Rule 147 is a transactional exemption only. Securities Act Release No. 5450, at 3 (Jan. 7, 1974), [1973-1974 Transfer Binder] FED. SEC. L. REP. (CCH) $\{79,617$, at 83,649 . Since it is only the sale by the issuer that is exempt, it is possible to argue that persons purchasing from issuers would become underwriters if they resold the securities after taking with a view to distribution. One could argue that the significance of the resale provision of the Rule was only to prevent the destruction of the issuer's exemption by resales made by purchasers. Some support for this position can be found in the language of preliminary note 4 to Rule 147, which states: "The rule provides an exemption for offers and sales by the issuer only. It is not available for offers or sales of securities by other persons." 17 C.F.R. $\$ 230.147$ (preliminary note 4) (1977) (emphasis added).

Such an interpretation, however, could destroy the effectiveness of the resale provision and severely circumscribe the attractiveness of Rule 147. At least one author has considered this problem and concluded that resales are legal for the purchaser in a Rule 147 transaction. Kant, supra note 151 , at 93.

166. As a rule of thumb, this author attempts to keep the legal expense of a stock issue to five percent or less of the amount realized. In Rule 147 offerings, absent unusual complications or problems caused by compliance with state Blue Sky laws, there is usually little trouble complying with this self-imposed constraint, even if the offerings are as small as $\$ 50,000$.

Since qualification for the intrastate exemption will limit the offering to a single state, the Blue Sky problems should be minimized. One can typically avoid registration under the Blue Sky laws by qualifying for the small issue exemption that is found in most state statutes. See, e.g., KY. REV. STAT. § 292.410(1) (1969); Ill. ANN. STAT. ch. 121 1/2 \$ 137.4(G) (Smith-Hurd 1960); IND. CODE ANN. § 23-2-1-2(b)(10) (Burns 1972); Mich. COMP. LAWS ANN. § 451.802(b)(9) (1967). One problem encountered in qualifying corporations for the small issue exemption in 
4. Prior Illegal Offers and Sales. The problem of prior illegal offers and sales, however, was not adequately treated by the Commission in Rule 147. The Commission promulgated the same safe harbor provisions ${ }^{167}$ that it subsequently adopted in Rule 146,168 and those provisions have been discussed earlier. ${ }^{169}$ Restating briefly, the automatic nonintegration provisions are applicable only if sales were made six months prior to the offering under Rule 147 and in strict compliance with an available exemption. ${ }^{170}$ For sales made illegally, the safe harbor provisions do not apply and the issuer is relegated to the traditional integration concepts to determine whether the prior offering will be considered part of the proposed offering under Rule 147. ${ }^{171}$ Because of the uncertainty of application of those traditional integration factors, the issuer probably will have to rely on the informal position of the Commission, which is that a one year wait is required to separate issues. ${ }^{172}$

As discussed earlier, the pressures and absurdity of this situation are intolerable. The attorney is placed in the impossible position of trying to explain to his client that a prior offer, which may well have been made in good faith and in reliance on advice from counsel, has contaminated any possible future offer. Further, the issuer who needs the capital is in an absurd position. He cannot tap the equity market notwithstanding the fact that his prior offer was thought to involve no illegality and perhaps was made on advice of counsel.

5. Summary. Notwithstanding the flaw resulting from potential integration problems, Rule 147 may well be the most manageable exemption for the small issuer. One advantage is the low cost associated with compliance, since one is not required to gather the extensive information required in a registration statement, Regulation A offering or Rule 146

Kentucky is the demand for disclosure often made by the Kentucky Division of Securities. In order to permit offers in excess of a certain number, which is permissible under KY. REv. STAT. $\S 292.410(1)$ (1969), the Division usually will demand certain disclosures be made to the division about the issuer. This can increase cost, although the Division's demands are normally reasonable and do not increase costs to the prohibitive level.

It is interesting to note that while the language of some states' Blue Sky laws permit the director of the securities departments to increase the number of offerees permissible under the small offering exemption, see, e.g., IND. CODE ANN. § 23-2-1-2(b)(10) (1972); KY. REV. STAT. § 292.410(1) (1969), the language of other state laws does not appear to authorize such action, see, e.g., ILl. ANN. STat. ch. 121 1/2, § 137.4(E) (Smith-Hurd 1960); Mich. CoMP. Laws ANN. § 451.802(b)(9) (1967).

167. 17 C.F.R. $\$ 230.147(b)(2)$ (1977).

168. Id. $\$ 230.146(\mathrm{~b})$. For a discussion of the "safe harbor" provisions of Rule 146, see text accompanying notes 47-52 supra.

169. See text accompanying notes 47-51 supra.

170. Hicks 473-74. For the same conciusion in the context of Rule 146, see Kinderman, supra note 22 , at 935 .

171. See Kant, supra note 151 , at $78-81$.

172. Goldman, supra note 59 , at 182. 
offering. Rule 147 also contains fair and intelligible resale provisions. Furthermore, it possesses the certainty so obviously lacking in the common law of section 3(a)(11). There are, however, two significant drawbacks to the Rule. The first is that an issuer is limited to tapping only the local market for capital, which often makes the exemption unacceptable for the issuer. The second is that there is no remedy for the problem of the prior illegal offers or sales that can destroy a proposed Rule 147 offering.

\section{Conclusions and Proposed Changes}

In the final analysis, there are four reasons why the 1933 Act does not work for small issuers: excessive costs, lack of clarity in the requirements to be met, unavailability of reasonable resale provisions and contamination caused by prior illegal offers or sales of securities. This is not to say that the Commission can eliminate all of these problems by a simple, magical stroke of its administrative wand. There is, however, room for improvement.

\section{A. Relative Reduction of Required Costs.}

Prior to the enactment of Rule $240^{173}$ the cost of compliance with the 1933 Act was a substantial problem for the small issuer. Today, however, the cost of compliance with the 1933 Act generally is not exorbitant, ${ }^{174}$ although one must have a complete familiarity with the 1933 Act in order to place the offering under the exemption that is most advantageous in terms of risk and expense. For any offering up to $\$ 100,000$, Rule 240 generally will be the most inexpensive exemption, although there should not be a substantial cost difference between Rule 240 and the intrastate exemption of Rule 147 , since neither of the rules requires any disclosure to offerees. Furthermore, Rule 240 requires no offeree qualification and thus no investigation by the issuer of the background of potential offerees. Rule 147, however, does have an offeree qualification requirement, ${ }^{175}$ although the procedures necessary to ensure that the offerees are residents of a particular state generally are not burdensome.

173. Rule 240 became effective on Mar. 15, 1975. 40 Fed. Reg. 6487 (1975).

174. It is this author's opinion that completing an offering at a cost of less than five percent of the total issue price is not exorbitant. See note 166 supra. It should be noted, however, that his definition of "exorbitant" does not necessarily comport with that of many small issuers. Typically, small issuers first groan and then fulminate when told the extent of the legal expenses necessary to comply with the state and federal securities laws.

This is due to two factors. First of all, it is difficult for small issuers that have never had any contact with the 1933 Act to understand why they should have to comply with its seemingly hyper-technical provisions. They can understand that they should not make material misstatements, but they do not understand why they should have to meet the technical disclosure requirements. Secondly, the attorney is constantly faced with the argument that "John Jones" company sold stock and he didn't do all this." In fact, it is true that small issuers constantly violate the $1933 \mathrm{Act}$, and it becomes difficult to convince a client that it is to his advantage to pay $\$ 8,000$ to do something that his friend or competitor did for much less.

175. 17 C.F.R. $\$ 230.147$ (d)(2) (1977). 
For offerings in excess of $\$ 100,000$, the most attractive exemption from a cost point of view is obviously the intrastate exemption provided by Rule 147. The absence of any requirement for disclosure or any limitation on the qualifications of offerees makes compliance with Rule 147 decidedly cheaper than the alternative of a private placement.

The more complex planning problems in relation to cost control arise where the offering is in excess of $\$ 100,000$ and does not qualify for an intrastate offering under Rule 147. Except in somewhat unusual situations, ${ }^{176}$ these offerings require some disclosure under Rule 146 or Regulation $\mathrm{A}$ and, as a result, the cost of compliance increases significantly. When offerings reach this size, however, the appropriateness of disclosure from a policy perspective becomes manifest. From the point of view of the issuer, the increased size of the offering causes the costs of disclosure to be a smaller percentage of the capital generated by the sale and thus less of an unfair burden. In addition, larger offerings present the opportunity for more extensive losses by more investors, which increases the need for disclosure by the issuer.

Accordingly, a rule requiring detailed disclosure for sales of stock in excess of $\$ 100,000$ is a sound rule, provided that the cost of the disclosure is not oppressive to the issuer. Consistent with this it may be appropriate for the Commission to amend Rule 146 to provide that an issuer can supply access in private offerings of less than $\$ 500,000^{177}$ by providing purchasers with the same kind of information that would be contained in a notification $^{178}$ filed under Regulation A of the 1933 Act. This would significantly reduce the cost of complying with Rule 146 while still providing the disclosure necessary for an informed business judgment.

One final but very significant cost problem, however, is beyond the control of the SEC. That is the cost associated with qualifying an offering

176. Under Rule 146, the issuer is not required to make any disclosure if all purchasers have access to the "information that is specified in Schedule A." Id. § 230.146(e)(1). A note to the subsection makes it clear, however, that access "can only exist by reason of the offeree's position with respect to the issuer. Position means an employment or family relationship or economic bargaining power that enables the offerees to obtain information from the issuer in order to evaluate the merits and risks of the prospective investment." Id. $\$ 230.146(\mathrm{e})$ (note).

177. The amount of $\$ 500,000$ may be appropriate since that is the maximum amount that can be offered under a Regulation A offering. 17 C.F.R. \& 230.254 (1977). Since the Commission has permitted these smaller public issues to be made with the more limited information contained in a notification, it would seem consistent to permit the same information to be sufficient for a private offering of that limited amount.

178. For a listing of the information contained in a notification, see 3 PRENTICE-HALL SEC Compliance: Financial Reporting and Forms if 63,001-63,189 (S. Weinstein, D. Schechtman \& M. Walker eds. 1976). The Commission has published a release proposing an amendment to Rule 146 that would permit the disclosure required by the rule to be satisfied by disclosing the information required by Schedule I of Regulation $A$, if the offering is $\$ 500,000$ or less. Securities Act Release No. 5913 (Mar. 6, 1978), [Current] Fed. SEc. L. ReP. (CCH) I 81,532 . 
under the Blue Sky laws of the states in which the offering is to take place. Although it usually is possible to avoid registration in a particular state, ${ }^{179}$ compliance with state securities statutes does increase the expenses associated with the offering, especially when the offerees reside in a number of different states. For example, the attorney for the issuer must either research each state's laws himself or obtain an opinion from local counsel that the offer to the resident of each state does not violate that state's securities laws. Obviously, this adds to the expenses an issuer must absorb.

In summary, the cost to the small issuer of complying with the 1933 Act is generally not exorbitant, especially when considered in light of the legitimate need to force disclosure in situations where significant amounts of securities are sold to the public. Perhaps the one area of criticism is the extensive disclosure necessary to qualify a small offering under Rule 146. When, however, one considers the states' Blue Sky laws, the picture may change dramatically. Especially where the issuer plans to obtain financing from investors in a number of different states, compliance with the varied Blue Sky laws of the states involved may push costs to an unacceptable level.

\section{B. Attitude Favorable to Simplification and Clarification.}

Since 1972 the Commission has adopted a number of rules that have brought a measure of clarity to the exemptions from registration. Rules 144, $146,147,237$ and 240 are worthy of note as legitimate attempts by the Commission to reduce uncertainty. There is, however, a significant amount of uncertainty remaining in the Act and the rules. Under Rule 146, for example, the concepts of "access" 180 and "sophistication" 181 are nebulous; under Rule 147, the definition of "doing business"182 needs persistent attention by the Commission in order that it may be better understood by the securities bar.

To the extent that the Commission's rule-making activity since 1972 indicates a commitment to the reduction of uncertainty, it is commendable and should be continued with vigor. In pursuit of this goal the Commission should foresake the technique of permitting apparent uncertainty to be resolved on a case-by-case basis and instead should adopt an attitude of aggressiveness toward the reduction of uncertainty in the securities acts. Quite clearly the Commission never again should permit an exemption to lie

179. Most states have a small offering exemption that usually permits offers or sales to no more than a certain limited number of persons. For example, in Kentucky an issuer can make offers to ten persons during a twelve month period. KY. REv. STAT. $\$ 292.410(9)(1969)$. See also note 166 supra.

180. 17 C.F.R. $\$ 230.146($ e) (1977).

181. Id. \$ 230.146(d).

182. Id. $\S 230.147(\mathrm{c})(2)$. 
in the fallow state in which the intrastate exemption lay prior to the adoption of Rule 147. This is not to advocate that the Commission should or even could resolve every uncertainty with a new rule. That would be an intolerable administrative burden for the Commission and would unnecessarily complicate an already complex area of the law. What is critical here is the attitude of the Commission. The Commission should not be reluctant to exercise its rule-making power in resolving troublesome issues. Rather, the Commission should seek out and resolve significant areas of uncertainty by amending inadequate old rules and adopting appropriate new rules.

\section{Reasonable Restrictions on Resale.}

The special problems that investors in small issuers have in reselling their stock could be substantially alleviated by the Commission. As stated earlier, ${ }^{183}$ the problem basically is that once securities are purchased from a small issuer under Rule 146, Rule 240 or section $4(2)$, the securities become "restricted" and can be resold only if the investor can qualify for an available exemption. Unfortunately, Rule 144 and Rule 237, which provide exemptions for investors holding restricted securities, are not workable alternatives for investors in small issuers. What is therefore needed is a new rule that will permit an investor in a small company to resell in situations where both the need for protection of the public and the need of investors to resell securities could be properly served.

The balance could properly be struck by a new rule that permitted the resale of a limited amount of securities (perhaps $\$ 50,000$ every six months) after the securities had been beneficially owned by the investor for two years, provided that the sales were made in negotiated transactions in which no remuneration was paid for the selling efforts of a third person. It is submitted that such a rule would remove the unnecessary impediments to resales, while ensuring that the policy considerations behind section 4(2), Rule 146 and Rule 240 are not violated.

A requirement that sales be made only in negotiated transactions would limit the selling mechanism to one that would permit the least chance of abuse. Traditionally, one of the approaches taken by the Commission to limit abusive selling techniques has been that typified by Rule 144, which requires that sales be made only in "'brokers' transactions." 184 Although this constraint effectively throttles the more aggressive selling techniques, investors in small issuers frequently cannot comply with this requirement. ${ }^{185}$

Accordingly, it would seem appropriate to limit resale to negotiated transactions, since the Commission has also used that technique to dampen

183. See text accompanying notes 61-96 supra.

184. 17 C.F.R. § 230.144(f)-(g) (1977).

185. See text accompanying notes 69-75 supra. 
excessive selling strategies. ${ }^{186}$ To require investors in small companies to sell only in face-to-face, negotiated transactions, without the services and efforts of any paid professional, would help eliminate the more aggressive techniques that could be used by an unconstrained professional dealer. More importantly, the use of negotiated transactions would permit the purchaser access to the seller, who hopefully would be a source of material information about the issuer. This may be especially beneficial in the case of sales by investors in small, closely held issuers, since those investors tend to have more information about the company than do their counterparts in larger, more widely held corporations.

The requirement of a two year holding period would accommodate the need to provide a reasonable resale alternative for the original purchaser, while still preventing a circumvention of the purposes of section 4(2), Rule 146 and Rule 240. Perhaps the most important aspect of such a holding period is that it would end the current discrimination against the investor in a small company. Presently, the investor in a small company is relegated to the five year holding period of Rule $237^{187}$ while the investor in an actively traded company can sell after two years under Rule $144 .{ }^{188}$ This seems manifestly unfair, and provides an impediment to capital formation by small issuers who are forced to accept only investors that can commit capital for a period in excess of five years.

Finally, to permit sales of $\$ 50,000$ every six months would enable the investor in the small company to liquidate his holdings within a reasonable time after the initial holding period of two years. Rule 237, practically the only exemption that an investor in a small company can utilize to resell his restricted securities, presently forbids sales in any twelve month period in excess of " 1 percent of the securities of the class outstanding." "189 As has been discussed earlier, ${ }^{190}$ this limitation discriminates against the investor in the small company, since it could be more than a decade before he could fully liquidate under Rule 237. The Commission should develop an alternative that would allow an investor in a small issuer to resell at some more reasonable rate.

\section{Elimination of Potential Contamination by Integration.}

Of all the problems faced by the small issuer, contamination by prior illegal offers perhaps would be the most difficult for the Commission to remedy. Some relief could be provided, however, by modifying the safe

186. Rule 237 requires that the sales be "bona fide sold in negotiated transactions otherwise than through a broker or dealer." 17 C.F.R. $\$ 230.237$ (a)(4) (1977).

187. Id. $\$ 230.237(\mathrm{a})(3)$.

188. Id. $\S 230.144(\mathrm{~d})(1)$.

189. Id. $\& 230.237(\mathrm{~b})$.

190. See text accompanying notes 83-87 supra. 
harbor provisions of Rule 146 and Rule 147 . The Commission should make at a minimum these automatic nonintegration provisions available to all prior sales, both legal and illegal, in order to provide at least some relief for the issuer that makes an unintentionally illegal offer of sale.

Even with this alteration, however, a small issuer could be effectively foreclosed from the capital market for up to six months, a situation that the Commission should permit to exist only if there is some important policy served by that rule. Shortening the restricted period to two or three months would be a blessing to the small issuer, but that still assumes away the most fundamental question: is it time for the Commission to scrap the single offering concept in favor of an offer by offer (or sale by sale) approach to the exemption? Under such an approach each offer would be viewed on its own merits; if the particular offer qualified for an exemption other offers or sales by the issuer would not destroy it.

Although it is beyond the scope of this Article to engage in a detailed analysis of the single offering concept, it should be pointed out that the integration concept does not appear to be essential to the functioning of the 1933 Act. If, for example, an issuer sells a security to $A$, a person who is a resident of the same state in which the issuer is incorporated and doing business, that sale to $A$ should arguably be exempt under the intrastate exemption, notwithstanding prior or subsequent action by the issuer. Because $A$ 's geographic proximity to the issuer provides an opportunity for him to discover material information about the issuer, ${ }^{191}$ the policy basis for the intrastate exemption is satisfied. It is not affected by any subsequent or former offer or sale by the issuer. Similarly, if an offer is made to a second person who is not a resident of the state but who can "fend for himself," that offer should be exempt under section 4(2) notwithstanding the prior offer. If any particular offeree can "fend for himself," there are sound reasons why the offer does not necessitate registration. Those policy reasons do not depend on the absence of prior offers or sales.

It is difficult to accept the single issue concept as one that is necessary to a scheme of securities regulation. ${ }^{192}$ It serves no valid purpose and is not essential to the philosophical underpinning of the 1933 Act's exemptions. It does, however, make it more difficult for issuers to meet the requirements of the 1933 Act, and therefore it has the pernicious effect of retarding capital formation.

191. For a discussion of the philosophical underpinning for the intrastate exemption, see note 145 supra.

192. In fact, the Commission may be moving away from an emphasis on the single issue concept. Rule 240, which was the last exemption promulgated by the Commission, does not include the traditional integration concept. 17 C.F.R. $\$ 230.240($ b)(note 1) (1977). 


\section{E. Summary.}

The present lot of a small issuer attempting to comply with the Securities Act of 1933 is not enviable. Varying combinations of exorbitant cost, insoluble ambiguity, contamination by prior offers and sales and onerous resale provisions create an unbearable burden for many small issuers. There are ameliorative steps that can be taken, and the Commission must so recognize and accommodate the special problems of the small issuer. 